Article

\title{
Optimization of Ternary Binders Based on Flash-Calcined Sed- iments and Ground Granulated Blast Furnace slag Using a Mix- ture Design
}

\author{
Ahmed Zeraoui ${ }^{1,2, *}$, Walid Maherzi 1,2, Mahfoud Benzerzour ${ }^{1,2}$ and Nor-Edine Abriak 1,2, \\ 1 Laboratoire de Génie Civil et géo-Environnement (LGCgE), Université de Lille, 59000 Lille, France. \\ walid.maherzi@imt-nord-europe.fr (W.M.); mahfoud.benzerzour@imt-nord-europe.fr (M.B.); \\ nor-edine.abriak@imt-nord-europe.fr (N.-E.A.) \\ 2 Institut Mines-Télécom (IMT) Nord-Europe, 59500 Douai, France \\ * Correspondence: ahmed.zeraoui@imt-nord-europe.fr (A.Z.)
}

\begin{abstract}
CO}_{2}$ emissions resulting from the production of cement is a major issue, but can be limited by the partial substitution of cement by low-carbon-impact additions. The aim of this study was the formulation of a ternary binder based on ordinary Portland cement (OPC), ground granulated blastfurnace slag (GGBS) and flash-calcined sediment (FCS), a dredged waste which was valorized after applying a new heat treatment: flash calcination. The used materials were physically, chemically and mineralogically characterized. The composition of the formulations was optimized using mixture designs. Five formulations, one reference formulation RM (100\% OPC), one binary formulation (50\% OPC/50\% GGBS), and three ternary formulations with a variable FCS rate $(10 \%, 15 \%, 20 \%)$, were selected and characterized fresh and hardened. Results showed that the incorporation of FCS reduced the workability and increased the density. In addition, a decrease in the initial setting time and the heat of hydration peak were observed. In the hardened state, the formulation containing $10 \%$ FCS showed 90-day mechanical strengths superior to that of RM. The use of FCS in ternary binders could reduce the environmental impact by reducing greenhouse gas emissions.
\end{abstract}

Keywords: sediments; circular economy; cement; ternary eco-binders; flash calcination method; mixture design

\section{Introduction}

Climate change in recent decades is alarming. Global warming is linked to the increase in greenhouse gas $\mathrm{CO}_{2}$ emissions, and the production of cement contributes to this. It is estimated that $5-8 \%$ of world $\mathrm{CO}_{2}$ emissions are due to the cement industry [1-4], while the production of one tonne of ordinary Portland cement (OPC) results in the emission of the equivalent of one tonne of $\mathrm{CO}_{2}$ [5]. The process of cement production consists of several steps (extraction of the raw material, transport, mechanical grinding, calcination, etc.), each leading to $\mathrm{CO}_{2}$ emission, especially when raw materials (limestone and clay) are heated to high temperature $\left(\approx 1450{ }^{\circ} \mathrm{C}\right)$ to obtain clinker. As the OPC is mainly composed of clinker (more than $95 \%$ by weight), limiting its negative impact on the environment involves reducing the amount of clinker.

To reach this goal, using mineral additions and particularly those derived from industrial by-products such as ground granulated blast-furnace slag (GGBS), as partial substitutes of cement (i.e., supplementary cementitious materials, SCMs) is an interesting alternative. As a matter of fact, in addition to reducing the environmental impact of cement, they enhance the mechanical properties and the durability of concretes $[6,7]$.

Among the commonly used mineral additions, one can cite GGBS, metakaolin, fly ash, silica fume etc., but also other types of co-products considered as waste such as 
dredged sediments. The latter can be valorized after undergoing adequate treatment, in cement matrices the properties of which they enhance.

Sediments are materials resulting from dredging operations essential to ensure the necessary draught for the navigation of ships. These operations generate large amounts of materials each year: more than $50 \mathrm{Mm}^{3}$ in France, about $300 \mathrm{Mm}^{3}$ in Europe [8], and about $300 \mathrm{Mm}^{3}$ in the USA [9]. In addition, according to the European Directive 2008/98/EC of 19 November 2008, dredged sediments are considered to be waste when they are removed from their natural environment. Managing these materials is a major technical, economic and environmental issue, and valorizing them in cementitious materials represents an interesting alternative [10]. The potential of dredged sediments to be used as SCMs is strongly linked to their mineralogical composition (calcite, quartz, kaolinite etc.), their physical characteristics (granulometry, BET specific surface area etc.), and their pollutant content. Heat treatment by calcination is an essential prerequisite for their use. Indeed, this step allows the vaporization of free water (at $100{ }^{\circ} \mathrm{C}$ ), the elimination of organic compounds (at $300^{\circ} \mathrm{C}$ ), the activation of clay minerals by the transformation of kaolin into metakaolin (at $530^{\circ} \mathrm{C}$ ), and the decomposition of calcium carbonates (at $\left.730{ }^{\circ} \mathrm{C}\right)$.

Heating leads to the dehydroxylation of crystallized and non-reactive kaolinite $\left(\mathrm{Al}_{2} \mathrm{O}_{3} \cdot 2 \mathrm{SiO}_{2} \cdot 2 \mathrm{H}_{2} \mathrm{O}\right)$ contained in clay, eliminating water, and to the destruction of its structure, resulting in metakaolinite, an amorphous and reactive aluminosilicate $\left(\mathrm{Al}_{2} \mathrm{O}_{3} \cdot 2 \mathrm{SiO}_{2}\right.$, or AS2), according to Equation (1) [11]. Thus, the temperature and the duration of calcination are two prime parameters on which the reactivity of sediments in the cement matrix depends.

$$
\begin{array}{ccc}
\mathrm{Al}_{2} \mathrm{O}_{3}\left(\mathrm{SiO}_{2}\right)_{2}\left(\mathrm{H}_{2} \mathrm{O}\right)_{2} & \mathrm{Al}_{2} \mathrm{O}_{3}\left(\mathrm{SiO}_{2}\right)_{2}\left(\mathrm{H}_{2} \mathrm{O}\right)_{x}+(2-\mathrm{x}) \mathrm{H}_{2} \mathrm{O} \\
\text { kaolinite } & \text { metakaolinite }
\end{array}
$$

Pozzolanic activity of calcined sediments was demonstrated in many works in the literature [9,12-15]. The study of Dang et al. [16] on composite cements based on Portland cement and marine sediment from Brittany, France, showed that the blended cement based on sediment calcined at $650{ }^{\circ} \mathrm{C}$ involved higher compressive strengths than the one based on classical calcareous filler. This result was attributed to the activation of clay minerals at $650{ }^{\circ} \mathrm{C}$. The same finding was made in Diouri et al.'s study [17] which showed that using $8 \%$ of calcined sediment improves the hydration of the cement-sediment blend and results in mechanical strengths equivalent to those obtained with a CEM I Portland cement. Faure et al.'s study [18] confirmed this by observing portlandite consumption when calcined sediments were used. Calcined sediments also allow the improvement of the durability of concrete as shown in Safer et al.'s study [19] where part of the cement $(10 \%$, $20 \%$ and $30 \%$ ) was substituted by sediment calcined at $750{ }^{\circ} \mathrm{C}$ for 5 hours. As a result, sediments led to a lower porosity in concretes because of the formation of supplementary C-S-H, and to better durability and especially a better resistance to sulfate attacks. Also, a reduction of connected pores was observed by Dang et al. [16]. These observations were confirmed in Amar et al.'s study [7] where a formulation composed of $10 \%$ calcined sediment as a partial replacement of cement had a lower water porosity compared to that of the control mortar, hence a better resistance to freeze/thaw cycles and to external sulphate attacks.

As well as direct calcination (in a traditional furnace), the flash calcination treatment leads to the complete activation of clay minerals in sediments with appearing amorphous phases [20]. Calorimetry tests showed that calcined sediments first enhance the hydration of the minerals of Portland clinker by the filler effect, and then contribute after 3-7 days to the development of strength by the formation of supplementary hydrates during the pozzolanic reaction [14,20,21]. Amar et al. [22] showed in a comparative study on one material that the sediment treated by flash calcination has a pozzolanic activity superior to that of sediments calcined in a traditional kiln. Moreover, the energy consumed for flash calcination is estimated to be around $2 \mathrm{GJ} / \mathrm{t}$ of sediment $[23,24]$ whereas about $8 \mathrm{GJ}$ are needed 
for a tonne of pure clinker [5,22]. In addition to improving the mechanical properties of concrete, using flash calcined sediments allows reducing the carbon footprint by limiting the quantity of clinker used.

\section{Materials and Methods}

\subsection{Materials}

The ternary binders studied in this work are composed of OPC, GGBS and FCS.

The used cement was a CEM I $52.5 \mathrm{~N}$ cement, compliant with the European standard NF EN 197-1, 2012 [25]. This cement is composed of more than 90\% clinker and 5\% secondary components. It is characterized by a low gypsum content. The compressive strength of a normalized mortar obtained with this type of cement is $52.5 \mathrm{MPa}$ at 28 days according to the European standard NF EN 196-1 [26] and the setting time of the cement is inferior to $240 \mathrm{~min}$.

Class A slag (Ecocem) compliant with NF EN 15167-1, 2006 [27] was also used. The vitrification rate of this type of slag exceeds $90 \%$. Compared to OPC, this co-product needs $20 \%$ less energy and decreases $\mathrm{CO}_{2}$ emissions by $10 \%$ [28].

Dredging sediments used as mineral additions in this study were marine sediments dredged in the Grand Port Maritime de Dunkerque (GPMD) harbour, located in the North of France. After dredging, sediments were transported to the laboratory, homogenized and dried in an oven at $60{ }^{\circ} \mathrm{C}$ to decrease their water content.

\subsection{Sediment treatment: grinding and flash calcination}

The treatment of sediments is a necessary step to optimize their use as SCMs in a cementitious matrix. The grinding allows obtaining fine sediment particles, to enhance their specific surface area and thus their reactivity $[13,23]$. The pozzolanic potential of sediments also depends on the calcination conditions (temperature and duration) as the mineral phases in sediments and especially clayey phases are activated during this step [2931]. The choice of the optimal calcination temperature is crucial. Indeed, the reactivity of the calcined sediment is strongly linked to the temperature of exposure. During clay calcination, the degradation of clay minerals begins with the loss of intra-layer water and adsorbed water between $100{ }^{\circ} \mathrm{C}$ and $250^{\circ} \mathrm{C}$. Dehydroxylation of kaolinite begins between $300{ }^{\circ} \mathrm{C}$ and $400{ }^{\circ} \mathrm{C}$ and speeds up from $500{ }^{\circ} \mathrm{C}$ to $600{ }^{\circ} \mathrm{C}$ to form metakaolin.

In this study, a flash calcination treatment was chosen. This new calcination technique was initially developed for clays (kaolin) $[24,32,33]$ and was adapted to sediments $[8,20,21,23]$. It consists in an instant exposure of the material (about $1 / 10 \mathrm{~s}$ ) at very high temperatures (from $700{ }^{\circ} \mathrm{C}$ to $1000{ }^{\circ} \mathrm{C}$ ) in a rotary kiln, and then the rapid cooling of the material. Thanks to the partial destruction of the matter, this quick exposure enables the formation of new amorphous phases with a potential activation of the sediment. This method has several advantages compared to the conventional calcination method, namely the quickness of the calcination process, the temperature control, a decreased energy consumption, and an increased activation potential [34].

The sediments used in this study were ground and sieved at $120 \mu \mathrm{m}$ and then flashcalcined at $820^{\circ} \mathrm{C}$. These conditions were fixed after works by Amar et al. [28] on a binary matrix composed of OPC and the same sediments from GPMD. These works showed that the mechanical strengths of mortars containing treated sediments could be, under certain conditions, better than those of the control.

\subsection{Materials characterization methods}

All the used materials were characterized using physical and chemical methods. The particle size distribution and especially the $\mathrm{D}_{50}$ were determined thanks to a laser diffraction particle size analyser (LS 13320, Beckman Coulter). The absolute density was measured according to NF EN 1097-7, 2008 [35] with a helium pycnometer (AccuPyc 1330, Micromeritics). The measurement of the specific surface area allows the assessment of the 
fineness of the additions and thus indicates the pozzolanic reactivity. Here, it was assessed by the measurement of nitrogen adsorption by the BET method (Brunauer-Emmett-Teller) according to the NF EN ISO 18757 standard [36]. The water demand test was performed following NF EN 196-3, 2009 [37] with a Vicat apparatus Vicatronic I06 091 equipped with a 10-mm diameter needle. This test consists in introducing different amounts of water into the additions and mixing them to form a paste. The water demand of the pastes corresponds to the amount of water added to get a penetration depth equal to $6 \mathrm{~mm}$ of the Vicat probe.

The mineralogical characterization was carried out by X-ray diffraction (D2 Phaserdiffractometer, Brucker Co) using $\mathrm{CuK} \alpha$ radiation $(\mathrm{K} \alpha=1.78 \AA$ ) in the $2 \Theta$ acquisition range $1-60^{\circ}$ and set at $40 \mathrm{kV}$ and $40 \mathrm{~mA}$. This identification allows qualifying and quantifying the phases present in each addition.

\subsection{Materials properties}

The physicochemical characteristics of the powder are summarized in Table 1 . The particle size distribution (Figure 1) of GGBS was shown to be highly similar to that of cement, with very close values of $\mathrm{D}_{10}$ and $\mathrm{D}_{50}$ (Table 1 ). However, FCS shows a finer granulometry with $\mathrm{D}_{50}=5.75 \mu \mathrm{m}$, which is about two times less than OPC. This modification of fineness can be explained by the densification of the grains of the sediment during the heat treatment process [13]. In addition, a change into a more rounded shape of the sediments' particles is likely to occur due to the cyclonic air movement in the flash calcination unit [30][38]. These physical modifications concerning the fineness and the shape contribute to the improvement of the compactness of the formulations containing FCS and thus to the enhancement of the mechanical properties. The BET specific surface area of FCS is more significant than those of OPC and GGBS while the density of FCS is inferior to those of OPC and GGBS. The fineness and the BET specific surface area of FCS promote the reaction when they are used as SCMs [39][40]. Moreover, the water demand of FCS is superior to those of OPC and GGBS. It is indeed commonly admitted that the increase in the fineness and in the BET specific surface area lead to increased water demand, as the contact surface where water molecules can adhere increases [41][42]. In the fresh state, important water demand can be detrimental to workability.

Table 1. Physicochemical characteristics of OPC, GGBS and FCS.

\begin{tabular}{|c|c|c|c|c|}
\hline & Characteristics & OPC & GGBS & FCS \\
\hline \multirow{5}{*}{$\begin{array}{l}\text { Physical } \\
\text { properties }\end{array}$} & Density $\left(\mathrm{g} / \mathrm{cm}^{3}\right)$ & 3.21 & 2.91 & 2.64 \\
\hline & Surface area BET $\left(\mathrm{cm}^{2} / \mathrm{g}\right)$ & 9194 & 16102 & 59930 \\
\hline & Water demand (\%) & 32 & 33 & 53 \\
\hline & $\mathrm{D}_{10}(\mu \mathrm{m})$ & 1.01 & 1.04 & 0.95 \\
\hline & $\mathrm{D}_{50}(\mu \mathrm{m})$ & 10.7 & 9.82 & 5.75 \\
\hline \multirow{10}{*}{$\begin{array}{l}\text { Major oxides } \\
\text { (wt \%) }\end{array}$} & $\mathrm{Al}_{2} \mathrm{O}_{3}$ & 5.10 & 10.8 & 8.00 \\
\hline & $\mathrm{CaO}$ & 60.9 & 40.7 & 21.6 \\
\hline & $\mathrm{Fe}_{2} \mathrm{O}_{3}$ & 4.00 & 0.53 & 9.00 \\
\hline & $\mathrm{K}_{2} \mathrm{O}$ & 0.72 & 0.46 & 1.88 \\
\hline & $\mathrm{MgO}$ & 1.16 & 6.23 & 2.00 \\
\hline & $\mathrm{MnO}$ & - & 0.20 & 0.15 \\
\hline & $\mathrm{Na}_{2} \mathrm{O}$ & 0.67 & 0.33 & 2.00 \\
\hline & $\mathrm{P}_{2} \mathrm{O}_{5}$ & 0.46 & - & 0.41 \\
\hline & $\mathrm{SO}_{3}$ & 4.49 & 4.69 & 0.20 \\
\hline & $\mathrm{SiO}_{2}$ & 16.3 & 31.7 & 52.8 \\
\hline
\end{tabular}




\begin{tabular}{lccc}
$\mathrm{TiO}_{2}$ & 0.33 & 0.66 & 0.45 \\
$\mathrm{ZnO}$ & 0.25 & - & 0.12 \\
\hline
\end{tabular}

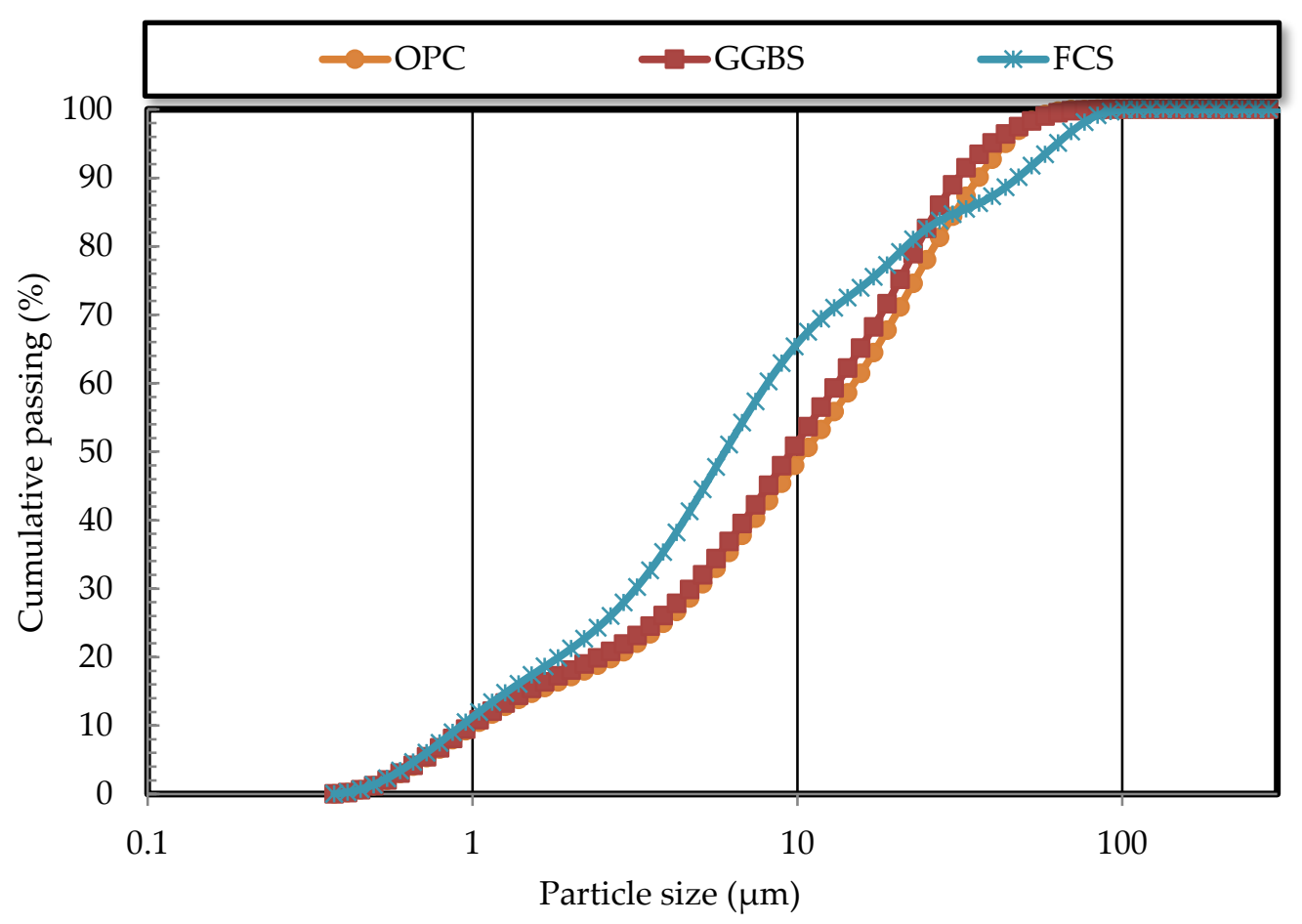

Figure 1. Particle size distribution of OPC, GGBS and FCS.

According to the results of the X-ray fluorescence analysis, the major elements composing these materials are silica, alumina and calcium. The silicon dioxide concentration is superior in FCS than in OPC and GGBS, with $52.8 \%$ in FCS vs. $16.3 \%$ in OPC and $31.7 \%$ in GGBS. During the pozzolanic reaction, silica reacts with portlandite $\mathrm{CH}$ to form additional C-S-H, which takes part in the densification of the cementitious matrix. In addition, the presence of $\mathrm{SO}_{3}$ in low concentrations in $\mathrm{FCS}$ reduces the risks of delayed ettringites formation and enhances durability. According to ASTM C618A on the assessment of the degree of pozzolanic reactivity of mineral additions; the sum of silica $\left(\mathrm{SiO}_{2}\right)$, alumina $\left(\mathrm{Al}_{2} \mathrm{O}_{3}\right)$ and hematite $\left(\mathrm{Fe}_{2} \mathrm{O}_{3}\right)$ must exceed $70 \%$ for the material to be considered for participation in pozzolanic reactions. FCS used in this study thus participates in pozzolanic reactions.

The result of the XRD mineralogical analysis is shown in Figure 2. FCS is composed of two major phases, quartz $\left(\mathrm{SiO}_{2}\right)$ and calcite $\left(\mathrm{CaCO}_{3}\right)$, and minor phases such as hematite $\left(\mathrm{FeO}_{3}\right)$, anhydrite $\left(\mathrm{CaSO}_{4}\right)$ and lime $(\mathrm{CaO})$. An investigation by Benzerzour et al. demonstrated the same results [9]. Phases such as anhydrite are initiated by the calcination process and may enhance the reaction of the cement hydration. Indeed, it is demonstrated that the presence of $\mathrm{CaCO}_{3}$, either as a chemical reagent or as a limestone constituent accelerates the hydration of C3S, and consequently leads to the rapid formation of C-S-H. 


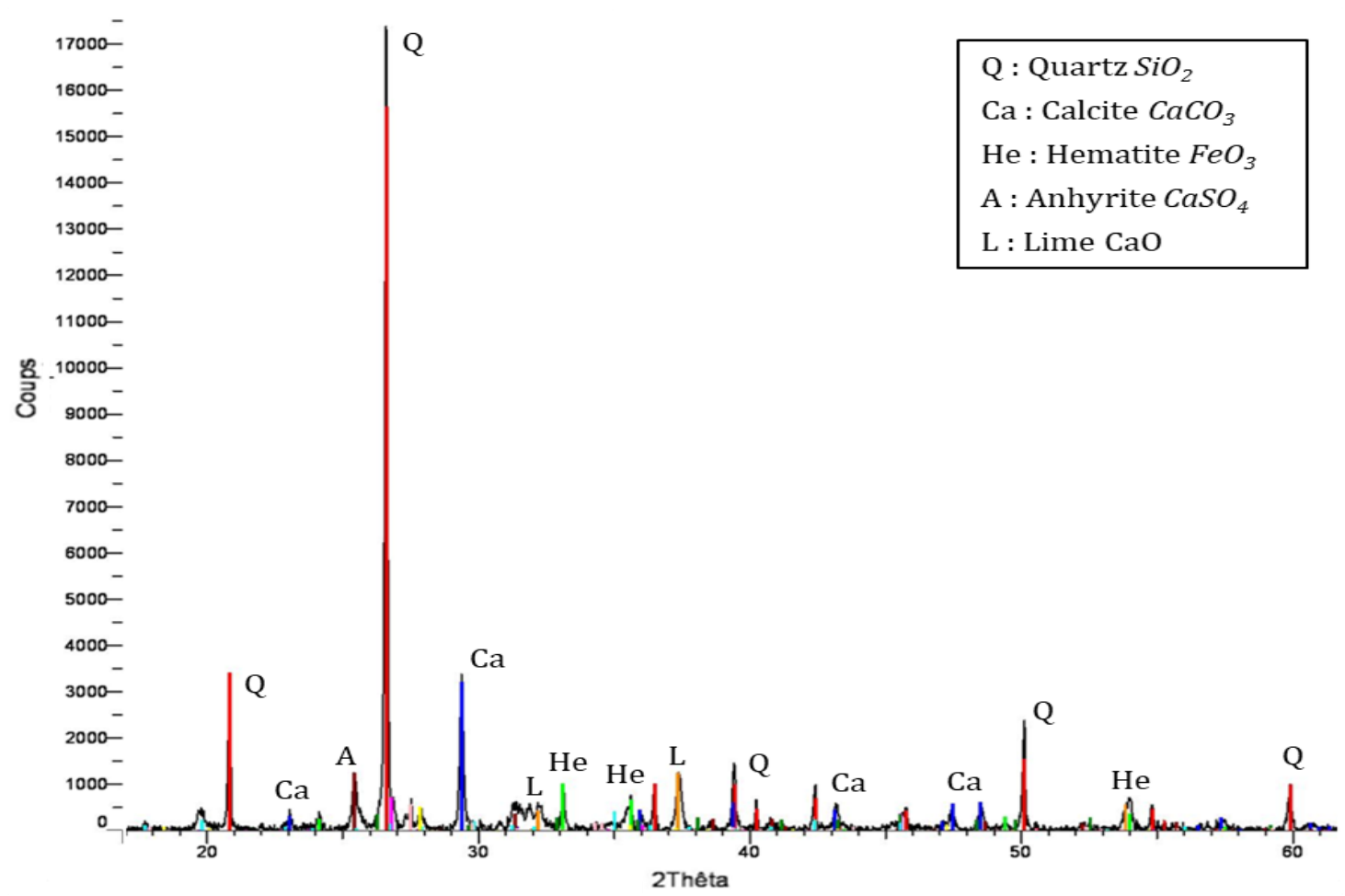

Figure 2. XRD analysis on FCS.

\section{Mix design approach}

\subsection{Experimental design and mixture model}

Design of experiments includes a set of methods based on statistics, which allow the mathematical modelling of the behaviour of a system. This is made possible after having carried out a limited number of tests chosen so as to maximize the amount of information obtained. Briefly, the influence of input variables called factors (and their possible interaction) on the system is quantified by the assessment of output variables or responses.

In this study, we chose to use the mixture design method which is particularly suited to formulation optimization issues and already used in the literature [43-47] to a mix containing OPC, GGBS and FCS.

Mixture designs are applied to mixes for which the amount of each constituent depends on that of the others. In our study concerning ternary mixes, the three factors $\left(X_{1}\right.$, $X_{2}, X_{3}$ ) are the volume proportions of OPC, GGBS and FCS respectively. In that way, the sum of the proportions of each constituent (factor) equals 1 or $100 \%$ (i.e., $X_{1}+X_{2}+X_{3}=1$ ). In our case, this constraint is as Equation (2).

$$
\sum_{i=1}^{n} X_{i}=O P C+G G B S+F C S=1(\text { or } 100 \%)
$$

The aim was to substitute up to 50\% of OPC with GGBS and FCS. The studied response-compressive strength at 90 days- was modelled after Scheffé quadratic regression model [48] given by Equation (3):

$$
\widehat{Y}=\sum_{i=1}^{q} \beta_{i} X_{i}+\sum_{i=1}^{q} \sum_{i<j}^{q} \beta_{i j} X_{i} X_{j}
$$

where $\widehat{Y}$ is the response predicted by the model (here, the compressive strength at 90 days), $\mathrm{q}$ is the number of constituents ( $\mathrm{q}=3$ : OPC, GGBS and FCS), $\beta_{\mathrm{i}}$ and $\beta_{\mathrm{ij}}$ are the model coefficients and $X_{i}$ is the volume proportion of each constituent. 
To define the experimental domain, the amount of cement was varied from $50 \%$ and $100 \%$, slag from 0 to $50 \%$, and FCS from 0 to $20 \%$. Table 2 represents the range of variation of the different materials.

Table 2. Lower and upper bounds of the experimental domain.

\begin{tabular}{cccc}
\hline Mixture Factor & $\mathbf{X}_{1}-$ OPC & $\mathbf{X}_{2}-$ GGBS & $\mathbf{X}_{3}-$ FCS \\
\hline Lower bound & 0.5 & 0 & 0 \\
Upper bound & 1 & 0.5 & 0.2 \\
\hline
\end{tabular}

Using Design Expert software (StatEase) the D-optimal design used consisted of 9 experimental points labelled from 1 to 9 and shown in Figure 3. Their composition is detailed in Table 3. The points were distributed evenly, which ensured a homogeneous coverage of the experimental domain. The analysis of the results of the mixture design was also carried out using Design Expert.

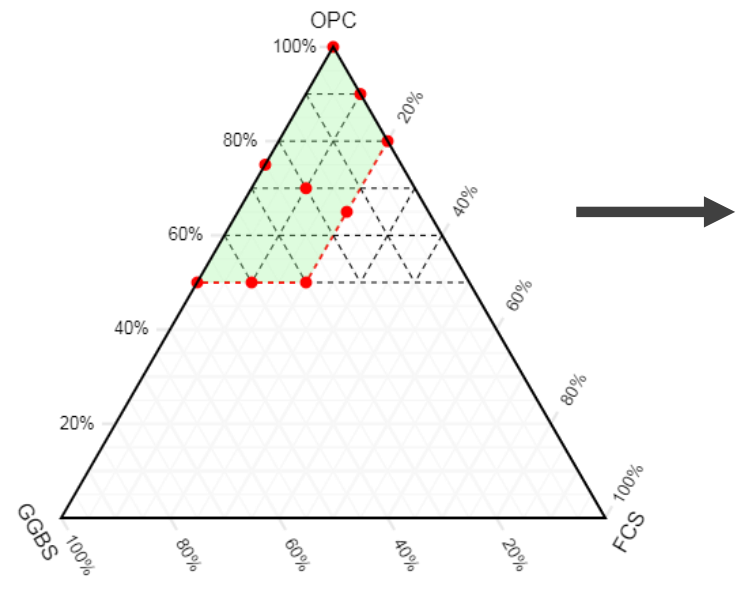

(a)

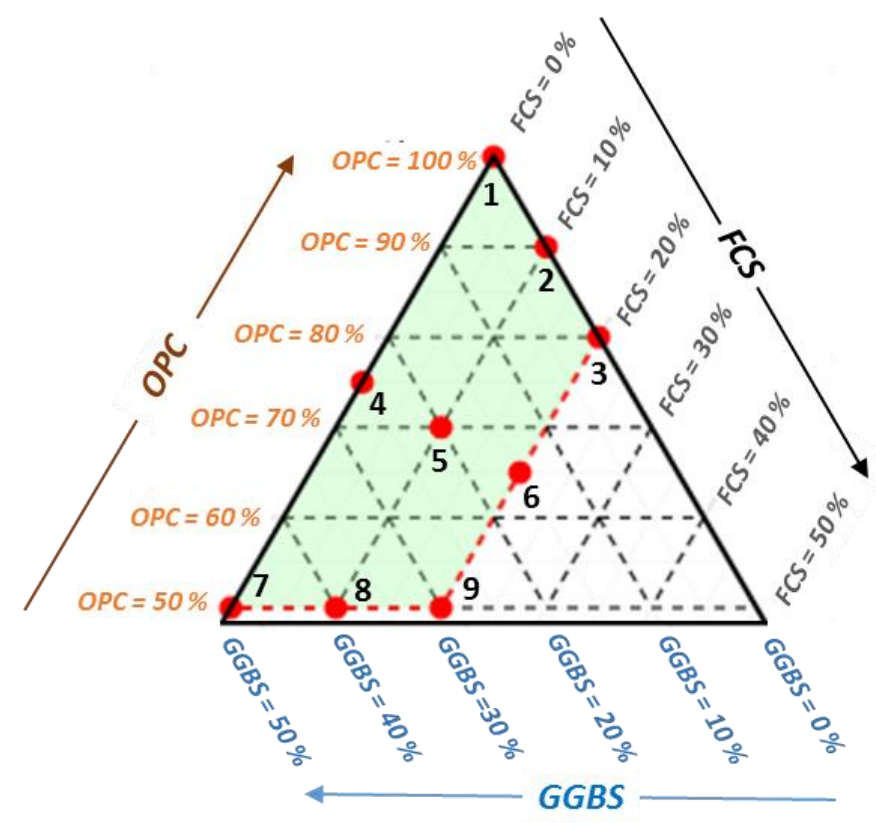

(b)

Figure 3. (a) Studied experimental domain; (b) Distribution of the chosen points inside the experimental domain.

Table 3. Composition of the 9 chosen points of the experimental domain (\%).

\begin{tabular}{ccccc}
\hline Exp. $\mathbf{N}^{\circ}$ & $\mathbf{X}_{1}-$ OPC & $\mathbf{X}_{\mathbf{2}}-$ GGBS & $\mathbf{X}_{3}$-FCS & Compressive strength 90 d (MPa) \\
\hline F1 & 100 & 0 & 0 & 66.45 \\
F2 & 90 & 0 & 10 & 62.72 \\
F3 & 80 & 0 & 20 & 55.56 \\
F4 & 75 & 25 & 0 & 66.75 \\
F5 & 70 & 20 & 10 & 64.24 \\
F6 & 65 & 15 & 20 & 57.02 \\
F7 & 50 & 50 & 0 & 61.50 \\
F8 & 50 & 40 & 10 & 68.67 \\
F9 & 50 & 30 & 20 & 58.67 \\
\hline
\end{tabular}


Starting from the experimental domain and the experimental points described in Section 3.1, 9 normalized mortar formulations were prepared following the European standard NF EN 196-1. Normalized sand compliant with ISO 679:2009 and for which $D_{\max }=2$ $\mathrm{mm}$, was used, with a water-to-binder ratio $\mathrm{W} / \mathrm{b}=0.5$. The substitution of OPC by the mineral additions was a volumetric substitution. The composition of the mortars is specified in Table 4.

Compressive tests were performed in triplicate on prismatic test samples of $4 \times 4 \times 16 \mathrm{~cm}$ (NF EN 196-1 [26]). After the samples were made, they were stored at $90 \%$ relative humidity for 24 hours before demoulding, then completely immersed in water and kept at $20^{\circ} \mathrm{C}$ until testing.

Table 4. Mortar composition.

\begin{tabular}{cccc}
\hline Mixture Factor & Binder & Normalised sand & Water $(\mathbf{w} / \mathbf{b}=\mathbf{0 . 5})$ \\
\hline Mass $(\mathrm{g})$ & 450 & 1350 & 225 \\
\hline
\end{tabular}

\section{Results and discussion}

\subsection{Mixture design}

\subsubsection{Mortars strength modelling}

The compressive strengths were measured after 90 days of curing (Table 3). The results were analysed with Design Expert software and presented in 2D as ternary diagrams and in 3D as surfaces (Figure 4).

These results show that the incorporation of FCS into the cement matrix improves the compressive strength. Indeed, the distribution of the responses (Rc90) of the experimental domain shows that the compressive strength increases with the FCS rate until it reaches its maximum at $10 \%$ FCS, then decreases above this rate of FCS. This can be observed in the curved shape of the 3D response surface (Figure 4) and suggests that the incorporation of $10 \%$ FCS is the optimum. Similar trends were noted in previous studies on sediments and calcined clays $[7,19,49]$. The increase of strength is linked to the physical and chemical activity of flash calcined sediments. This activity has already been the subject of several works in the literature $[13,15,20,24,50]$.

Moreover, a decrease of the mechanical strength can be observed in the use of binary binders: the compressive strength decreases from $66.45 \mathrm{MPa}$ for the control mortar to 61.50 MPa for the formulation with 50\% GGBS, and to 55.56 MPa for the formulation with $20 \%$ FCS. This reduction of strength can be explained by the cement dilution effect. On the contrary, the compressive strength grows for ternary formulations, even with $50 \%$ OPC substituted. In fact, the mix containing 40\% GGBS and 10\% FCS shows a 3.34\% increase compared to the reference formulation (100\% OPC), and an $11.6 \%$ increase compared to the binary formulation made of $50 \%$ GGBS. This increase in strength is attributed to the combined effect of the presence of GGBS and FCS. As reported in several studies, the synergy of the use of multiple SCMs allows reaching high strengths [51-55]. 


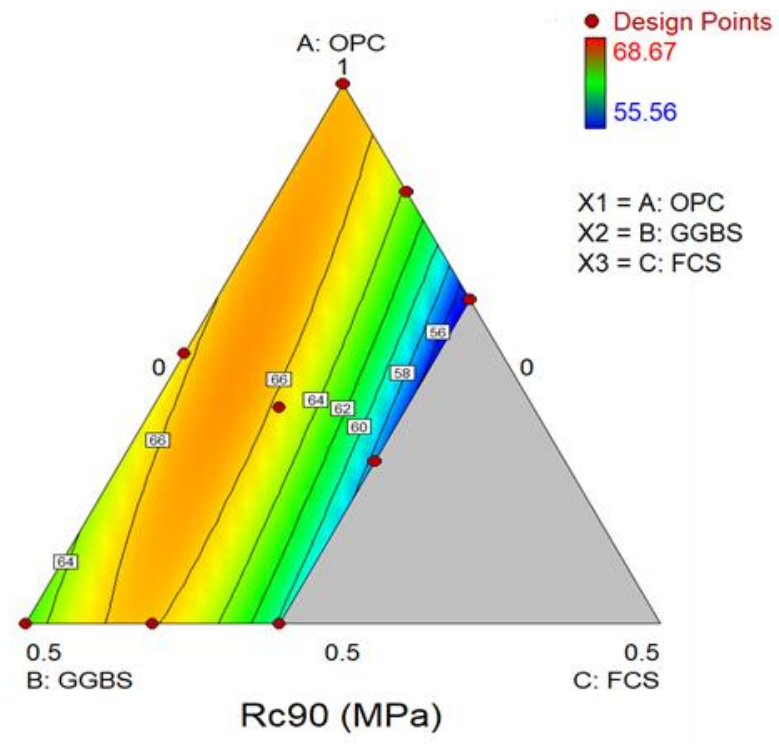

(a)

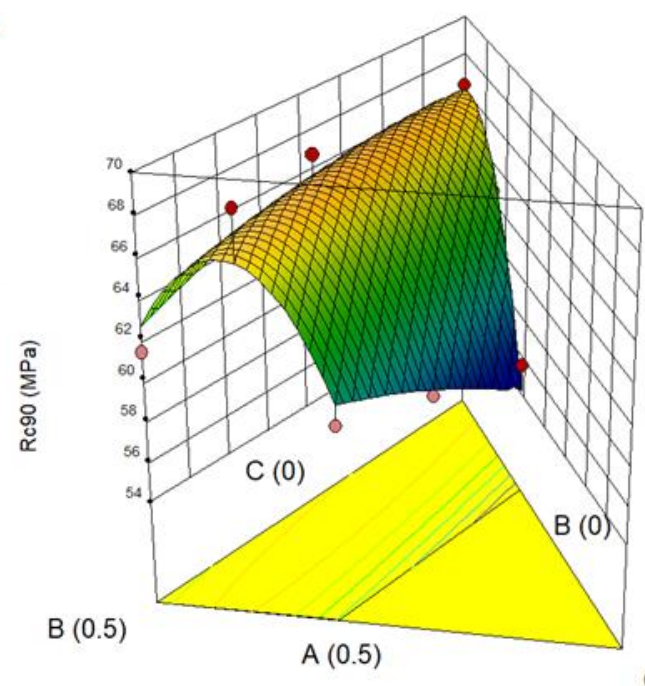

$C(0.5)$

Figure 4. 2D (a) and 3D (b) representations of 90-day uniaxial compressive strengths results.

\subsubsection{Prediction model and validation}

The fittest model is the quadratic regression model defined by Scheffé (Equation (3)). By applying this model, the generalized quadratic formula presented in Equation (4) is obtained.

$$
\mathrm{Rc}_{90}(\mathrm{MPa})=\left(\mathrm{C} \cdot \beta_{1}+\mathrm{L} \cdot \beta_{2}+\mathrm{A} \cdot \beta_{3}\right)+\left(\mathrm{C} \cdot \mathrm{L} \cdot \beta_{12}+\mathrm{C} \cdot \mathrm{A} \cdot \beta_{13}+\mathrm{L} \cdot \mathrm{C} \cdot \beta_{23}\right)
$$

Table 5 gives the values of the coefficients of the model.

Table 5. Coefficients of Scheffé quadratic model for the prediction of uniaxial compressive strength at 90 days.

\begin{tabular}{ccccccc}
\hline Coefficient & $\boldsymbol{\beta}_{\mathbf{1}}$ & $\boldsymbol{\beta}_{\mathbf{2}}$ & $\boldsymbol{\beta}_{\mathbf{3}}$ & $\boldsymbol{\beta}_{\mathbf{1 2}}$ & $\boldsymbol{\beta}_{\mathbf{1 3}}$ & $\boldsymbol{\beta}_{\mathbf{2 3}}$ \\
\hline & 66.48 & 51.87 & -247.47 & 12.43 & 315.42 & 451.91 \\
\hline
\end{tabular}

Equation (5) below can then be stated to predict the compressive strength at 90 days for mortars made of OPC (C), GGBS (S) and FCS (F):

$\mathrm{Rc}_{90}(\mathrm{MPa})=(66,48 \mathrm{C}+51,87 \mathrm{~S}-247,47 \mathrm{~F})+(12,43 \mathrm{C} \cdot \mathrm{S}+315,42 \mathrm{C} \cdot \mathrm{F}+451,91 \mathrm{~S} \cdot \mathrm{C})$.

The validation of the model described above was carried out by comparing the uniaxial compressive strengths at 90 days predicted by the model and the strengths experimentally measured for the same age. For this purpose, an extra formulation intended solely for the validation of the model was made and tested at 90 days following the experimental protocol defined in Section 3.2. The composition of this validation formulation is shown in Table 6.

Table 6. Composition and compressive strength of the formulation used to validate the model.

\begin{tabular}{|c|c|c|}
\hline \multirow{3}{*}{ Composition (\%) } & OPC & 50 \\
\hline & GGBS & 35 \\
\hline & FCS & 15 \\
\hline \multirow{2}{*}{$\begin{array}{c}\text { Compressive strength at } 90 \\
\text { days (MPa) }\end{array}$} & Predicted strength & 63.83 \\
\hline & 95\% confidence interval & {$[60.75-66.91]$} \\
\hline
\end{tabular}


Measured mean compressive

strength $( \pm \mathrm{SD})$

$64.90( \pm 0.70)$

Based on the results of the comparison between the strength obtained experimentally and the one predicted by the model, we can claim that the model suits well our data. Indeed, the mean compressive strength value at 90 days is within the $95 \%$ confidence interval centred on the mean predicted strength value. The defined quadratic model allows predicting the value of the compressive strength at 90 days with great accuracy.

To investigate the effect of the ternary structure (OPC + GGBS + FCS), 5 formulations including three ternary formulations based on GGBS and FCS (TSM), one binary formulation (BSM), and one reference formulation (RM) were chosen for a more thorough study. The compositions of the blended cements are presented in Table 7.

Table 7. Compositions of the blended cements (\%).

\begin{tabular}{cccc}
\hline Index & OPC & GGBS & FCS \\
\hline RM & 100 & - & - \\
BSM 50-0 & 50 & 50 & - \\
TSM 40-10 & 50 & 40 & 10 \\
TSM 35-15 & 50 & 35 & 15 \\
TSM 30-20 & 50 & 30 & 20 \\
\hline
\end{tabular}

\subsection{Fresh state properties}

The effect of the use of ternary binders based on GGBS and FCS on the fresh state properties was assessed through the flow test, the density, the air content, and the initial setting time.

The workability of the mortars was estimated by the flow table test and a flow mould of dimensions $70 \times 100 \times 60 \mathrm{~mm}$ [56]. Measurements were carried out $5 \mathrm{~min}$ after the mortars had been mixed. The fresh density was measured according to European standard NF EN 1015-6, 1999 [57] and the air content according to NF EN 1015-7 [58] by the pressure method using a device equipped with a manometer. Also, the initial setting time was measured using an automatic Vicat apparatus (Vicatronic) according to NF 193-3, 2017 [59].

Results obtained for these different tests are shown in Table 8.

Table 8. Properties of the mortars based on blended cement.

\begin{tabular}{cccccc} 
& RM & BSM 50-0 & TSM 40-10 & TSM 35-15 & TSM 30-20 \\
\hline Fresh density $\left(\mathrm{kg} / \mathrm{m}^{3}\right)$ & 2188 & 2151 & 2207 & 2212 & 2215 \\
Air content $(\%)$ & 7.2 & 6.6 & 4.0 & 4.1 & 4.5 \\
Flow $(\mathrm{cm})$ & 22.4 & 22.0 & 21.5 & 21.0 & 18.7 \\
Initial setting time $(\mathrm{min})$ & 256 & 338 & 318 & 311 & 308 \\
\hline
\end{tabular}

Flow table test results show that the use of FCS leads to a loss of workability, proportional to the rate of FCS present within the ternary matrix. This can be explained by the specific surface area of FCS, which differs from that of GGBS and OPC, leading to divergent behaviours regarding water. Besides, as observed in the materials characterization step, the water demand of FCS is far superior to that of OPC and GGBS. This leads to higher retention of water, which will no longer be available to act as an intergranular lubricant in the fresh state. 
An improvement of the density was also noted with FCS. It is attributed to the fineness of FCS and its rounded shape resulting from its treatment [38]. Thus, the use of FCS enhances the granular compactness and lowers the air content, leading to a better density in the fresh state.

The air content measurement test is in agreement with these findings. Results show that the use of a ternary system based on FCS and GGBS comes with a reduction of the air content. The use of fine SCMs allows filling in intergranular pores and increases the compactness of mortars at the same time [32].

Both BSM and TSM present a delay on the initial setting time compared to RM, attributed to the cement dilution effect as $50 \%$ of OPC is substituted. In fact, the amounts of the cement components (especially C3S) which are quickly hydrated in contact with water, are reduced [60-62]. Furthermore, the incorporation of FCS into the ternary system allows reducing this delay. An acceleration of the setting time, proportional to the rate of FCS in TSM, was observed. This accelerator effect on the setting might be due to the fineness of FCS, which promotes the fast development of hydrates through the nucleation effect $[9,63]$.

\subsection{Physical properties: Heat of hydration}

The hydration reaction undergone by cement when in contact with water is endothermic. The monitoring of heat of hydration in fresh mortar gives information on the reactivity of the different components of the binding matrix in contact with water. The heat of hydration was determined in compliance with NF EN 196-9, 2010 [64] by the semiadiabatic Langavant method. Following this method, a sample of fresh mortar was introduced into a semi-adiabatic calorimeter (CERILH) and the heat release was monitored as a function of time. The heating of mortar was then compared to the temperature of an inert sample in a reference calorimeter.

The heat of hydration $Q$ dissipated into the environment can thus be expressed by the following formula (Equation (6)):

$$
Q=\frac{\mathrm{C}}{\mathrm{m}_{\mathrm{C}}} \theta_{\mathrm{t}}
$$

where $C$ is the total heat capacity of the calorimeter $(\mathrm{J} / \mathrm{K}), \mathrm{m}_{\mathrm{C}}$ is the weight of binder $(\mathrm{g})$ and $\theta_{t}$ is the difference of temperature between the test calorimeter and the reference calorimeter $(\mathrm{K})$. The curves of the cumulated heats of hydration for each formulation are shown in Figure 5. 


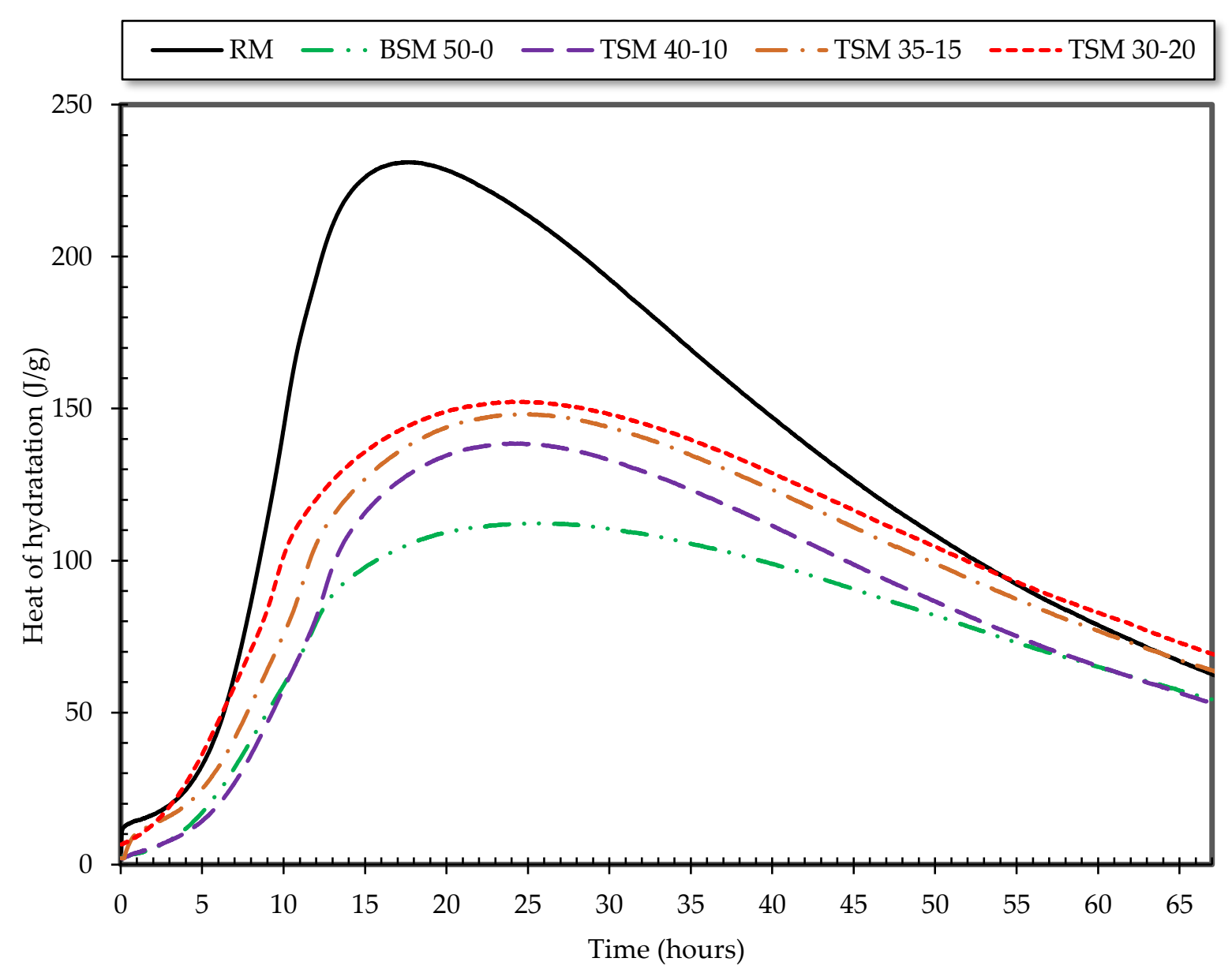

Figure 5. Evolution of the heat of hydration as a function of time for the different mortar formulations.

The results show that the substitution of $50 \%$ of OPC by FCS and BBGS reduces the heat of hydration, from $231.07 \mathrm{~J} / \mathrm{g}$ for RM to $146.29 \mathrm{~J} / \mathrm{g}$ on average for TSM, and $112.25 \mathrm{~J} / \mathrm{g}$ for BSM. This is due to the slow hydration of GGBS, as the formation of an acidic layer of aluminium hydroxide $\mathrm{Al}(\mathrm{OH})_{3}$ prevents water from accessing and dissolving the grains [65]. Moreover, the presence of FCS in the ternary system increases the heat of hydration compared to BSM. Increases are $26.29 \mathrm{~J} / \mathrm{g}, 35.87 \mathrm{~J} / \mathrm{g}$ and $39.85 \mathrm{~J} / \mathrm{g}$ for TMS 40-10, TMS 3515 and TMS 20-30, respectively, compared to BSM. Considering the fineness of calcined sediments $\left(\mathrm{D}_{50}=5.75 \mu \mathrm{m}\right)$ and their significant specific surface area, the pozzolanic reaction is sped up and particularly by nucleation effect $[63,66,67]$. The high reactivity results in the release of a supplementary amount of heat.

\subsection{Hardened state properties}

\subsubsection{Compressive and bending strengths}

In order to observe the effect of the use of ternary binders on the hardened state strengths, uniaxial compressive and bending strengths tests were carried out on three prismatic test samples $(4 \times 4 \times 16 \mathrm{~cm})$ complying with NF EN 196-1 [26]. Mechanical strengths were determined at 14, 28, 60 and 90 days. Figures 6 and 7 show the results obtained for the uniaxial compression and flexion tests, respectively. 


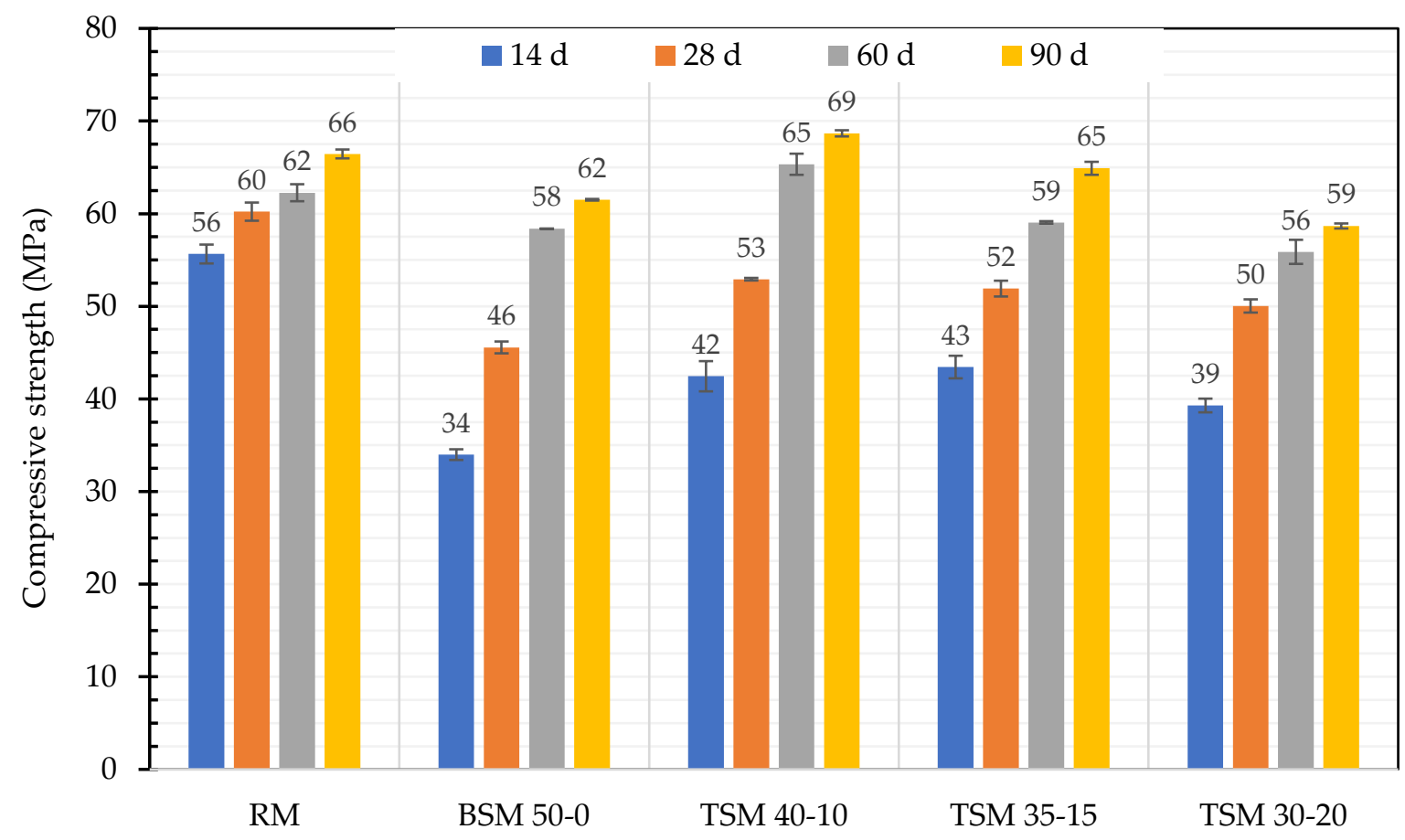

Figure 6. Evolution of the compressive strength.

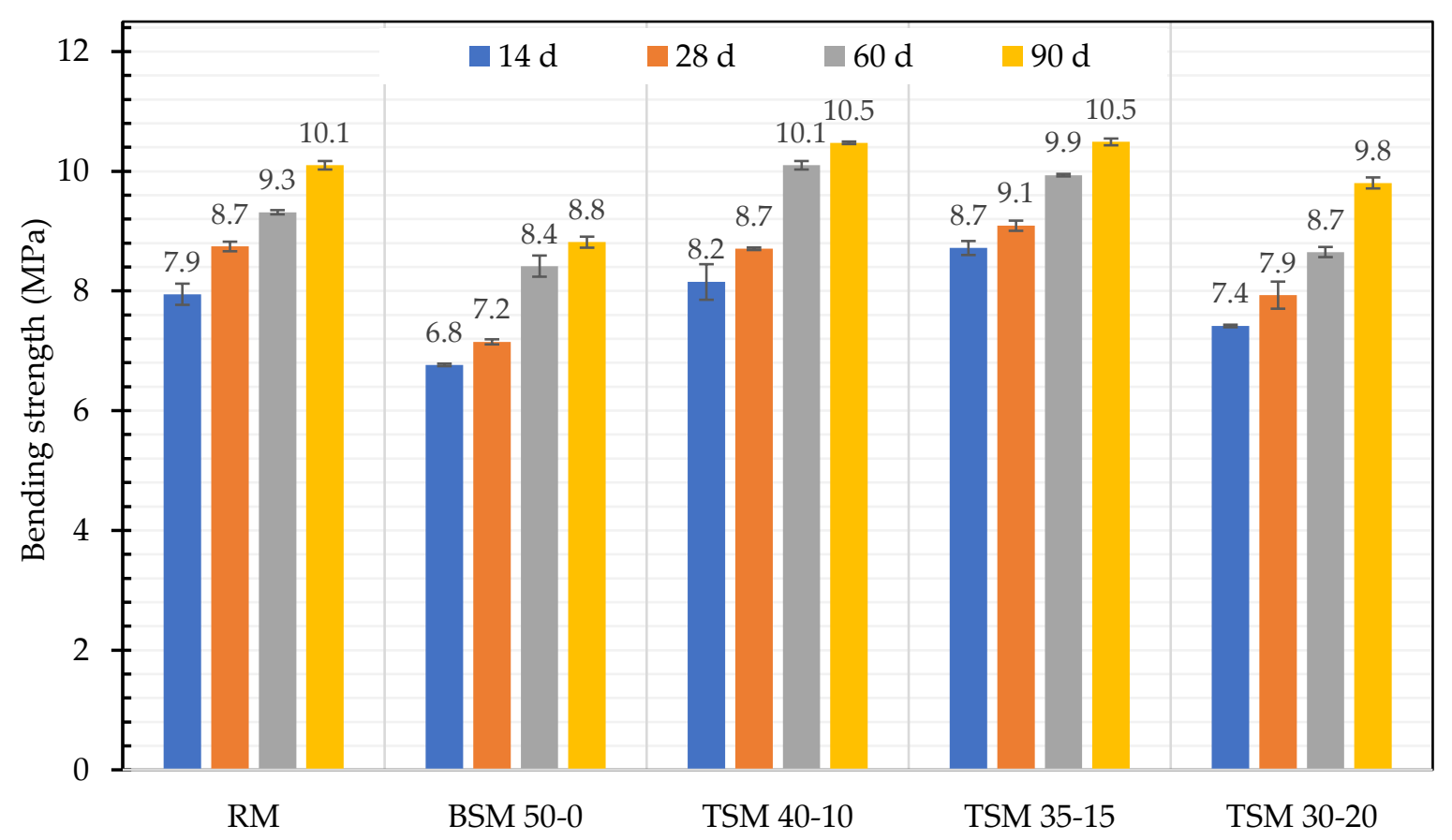

Figure 7. Evolution of the bending strength.

Results show that the compressive strength increases with the curing age for all formulations. At an early age (14 days), the strength of RM is superior to that of BSM and TMS. The latter contains 50\% OPC less and thus less C3S, which forms a resistant C-S-H gel upon its quick hydration in the short term. In addition, BSM and TSM long-term strengths increase significantly: between 14 and 90 days they rise by $80 \%$ for BSM 50-0 and by $53.34 \%$ on average for TMS, while RM strength only increases by $18 \%$. This may be due to the pozzolanic reaction of the additions $[13,68,69]$. Indeed, during the hydration 
of OPC, portlandite $\mathrm{Ca}(\mathrm{OH})_{2}$ is formed by the combination of $\mathrm{Ca}^{2+}$ and $\mathrm{OH}^{-}$released by alite (C3S) and belite (C2S). The latter reacts with silica $\mathrm{SiO}_{2}$ and alumina $\mathrm{Al}_{2} \mathrm{O}_{3}$ brought by FCS and forms more C-S-H according to Equation (7) as followed:

$$
3 \mathrm{CH}+2 \mathrm{~S} \longrightarrow \mathrm{C}_{3} \mathrm{~S}_{2} \mathrm{H}_{3}
$$

with $\mathrm{CH}=$ portlandite and $\mathrm{S}=\mathrm{SiO} 2$.

TSM 40-10 formulation composed of $40 \%$ GGBS and 10\% FCS shows a strength that exceeds that of RM from 60 days of curing, which is evidence of the high level of reactivity of FCS. This activity is linked to the physical and chemical aspects of those sediments: their granulometry is very fine, and the flash calcination treatment allows obtaining spherical particles, thus constituting nucleation zones favourable to the formation of hydrates. On the other hand, the chemical activation can be suspected, as elements found in sediments such as sodium sulfate $\mathrm{Na}_{2} \mathrm{SO}_{4}$ can activate slag [70,71]. Moreover, the activation of certain clayey phases of sediments (including kaolinite) by flash calcination also contributes to an increased pozzolanic reaction.

In accordance with compressive strengths results, bending tests results (Figure 7) show that formulations based on FCS have higher bending strengths than control mortars as early as 60 days of curing, for sediment levels up to $15 \%$.

\subsubsection{Dynamic elastic modulus}

The dynamic elastic modulus was assessed by the measurement of the fundamental resonance frequency according to NF EN 14146, 2004 [72]. In this test, mortar formulations undergo an instant and longitudinal mechanical impulse. With a device to record the resonance of the sample, the dynamic modulus is deduced from Equation (8):

$$
\mathrm{Ed}_{\mathrm{L}}(\mathrm{MPa})=4 \times 10^{-6} \cdot \mathrm{l}^{2} \cdot \mathrm{F}_{\mathrm{L}}^{2} \cdot \rho
$$

where $\mathrm{Ed}_{\mathrm{L}}$ is the dynamic elastic modulus $(\mathrm{MPa}), \mathrm{F}_{\mathrm{L}}$ is the fundamental resonance frequency $(\mathrm{Hz}), \rho$ is the density $\left(\mathrm{kg} / \mathrm{m}^{3}\right)$ and $\mathrm{l}$ is the length of the sample $(\mathrm{m})$.

Figure 8 shows the evolution of the dynamic modulus of all formulations as a function of time. An increase of the modulus is observed with the curing time. This may be explained by the pozzolanic activity, which allows obtaining new products of hydration. These take part in the densification of the cementitious matrix and thus in the improvement of the dynamic modulus. Besides, the dynamic modulus of TMS at 90 days is of the same order as that of RM, and even higher for TSM 40-10 and TSM 35-15.

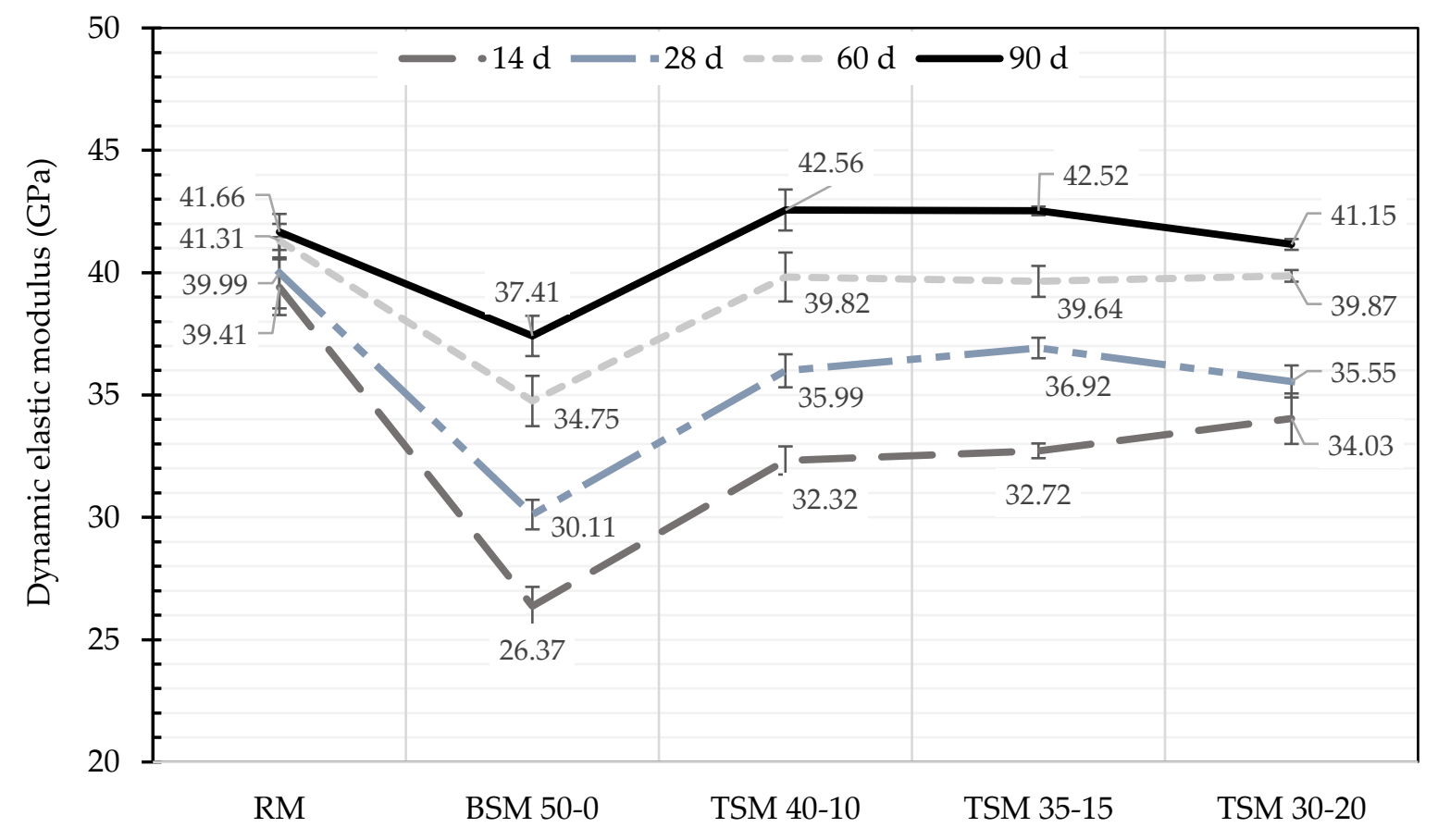

Figure 8. Evolution of the dynamic elastic modulus. 


\subsection{Microstructure characterization}

\subsubsection{Mercury porosity}

The distribution of porosity in mortars was determined by mercury porosimetry. The instrument enables the analysis of a wide range of porosities between $7 \mathrm{~nm}$ and $500 \mu \mathrm{m}$ in diameter. Measurements are made at low pressure for relatively large pore sizes, and high pressure for nanoporosities.

The characterization of porosity was measured at different ages (14, 28 and 90 days) after hydration was discontinued in order to monitor its evolution regarding the setting time for cement pastes.

Results shown in Figures 9 and 10 allow us to note that all formulations have a total porosity between 7.12 and $12.55 \%$, and that porosities decrease for all studied materials with age. At 14 days, the porosities of TSM are similar to those of RM (12\% on average). However, at 90 days, porosities of mortars containing FCS are lower than those of the control mortar. This suggests that the pozzolanic activity of flash calcined sediments and slag generates new hydrates, which allows filling in the total porosity and improves the density of the structure. Besides, the latter is linked to other factors such as the type of the formed hydration phases and the gelation degree for semi-crystallized hydrates (e.g., C$\mathrm{S}-\mathrm{H})$, the $\mathrm{Ca} / \mathrm{Si}$ ratio, the temperature of hardening, and the nature of the mineral additives $[73,74]$.

Figure 10 presents the pore size distribution in each formulation at 14, 28 and 90 days. These results show that the pore diameters in reference mortar RM are larger than those in ternary mortars containing FCS. Indeed, at 90 days, more than $63 \%$ of the pores contained in ternary matrices have a size smaller than $50 \mathrm{~nm}$, whereas this category accounts for less than $20 \%$ in RM. In addition, the highest concentration of porosities of TSM was observed for a diameter inferior to $20 \mathrm{~nm}$. Thus, the use of ternary binders leads to smaller pore sizes, which is beneficial to durability. According to the literature, four classes of structural porosity can be defined [75-77]:

- Class A: 1-25 nm. Typical of meso-gel porosities, it defines porosities between C-S-H chains formed in the matrix. The higher the density of porosity measured in this class, the more the amount of C-S-H gel in the matrix;

- Class B: 25-50 nm. Typical of microcapillary and mesocapillary porosities between groups of C-S-H chains;

- Class C: $50 \mathrm{~nm}-1 \mu \mathrm{m}$. Typical of a macrocapillary porosity in the structure of long CS-H chains;

- Class D: 1-10 $\mu \mathrm{m}$. Macroporosity linked to wall effects and the morphology of glass powder.

As seen in Figure 10, one can note that the use of ternary binders results in an increase of class A and class B porosities versus higher concentrations of class $\mathrm{C}$ porosities in the reference matrix. 


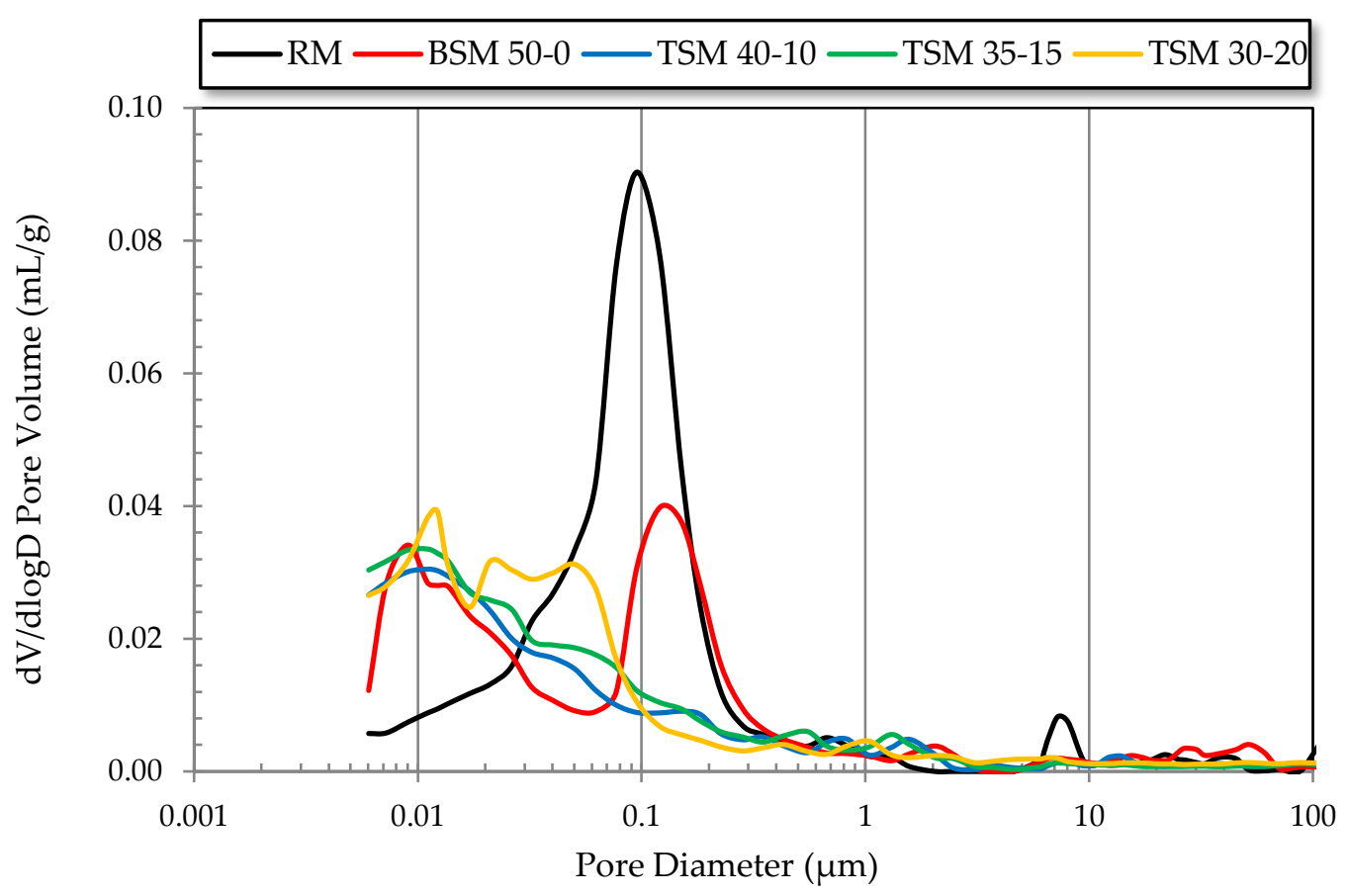

Figure 9. Pore distribution of studied samples at 90 days.

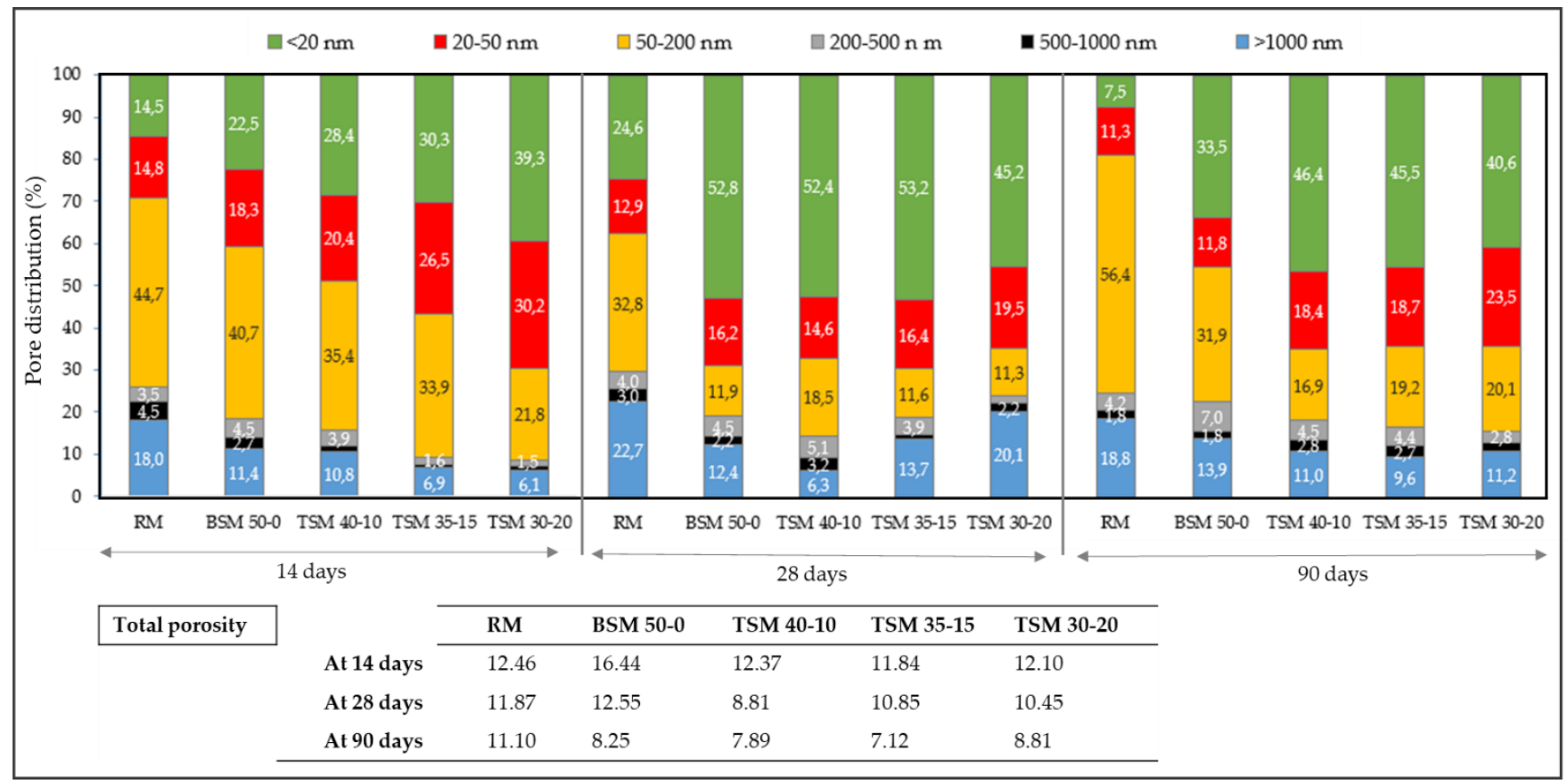

Figure 10. Total porosity and pore size distribution of studied samples at 14, 28 and 90 days.

\subsubsection{SEM observation}

SEM (Scanning Electron Microscopy) is a method allowing for the observation at a high resolution of the surface of samples, here fragments of mortar based on a ternary binder. Mortar fragments were metallized with platinum and observed with a table-top SEM (S-4300SE/N, Hitachi). SEM observations on the control mortar RM and the formulations based on GGBS and FCS at 90 days of cure are shown in Figure 11. Microscopic elements such as C-S-H gel, ettringite crystals or portlandite $(\mathrm{CH})$ can be observed. However, the microscopic observation results highlight the important presence of voids and 
portlandite in formulations containing cement only, whereas in ternary binder formulations, the porosity is filled with supplementary hydration products (C-S-H, C-A-H) resulting from the pozzolanic activity of additions (FCS and GGBS) [78]. Indeed, we can notice that the content of portlandite $(\mathrm{CH})$ is lower in the ternary binders than in the reference mortar RM. These observations confirm the results of the porosity evolution, which showed that the ternary formulation based on FCS and GGBS allows having a denser structure and a decrease of porosity.
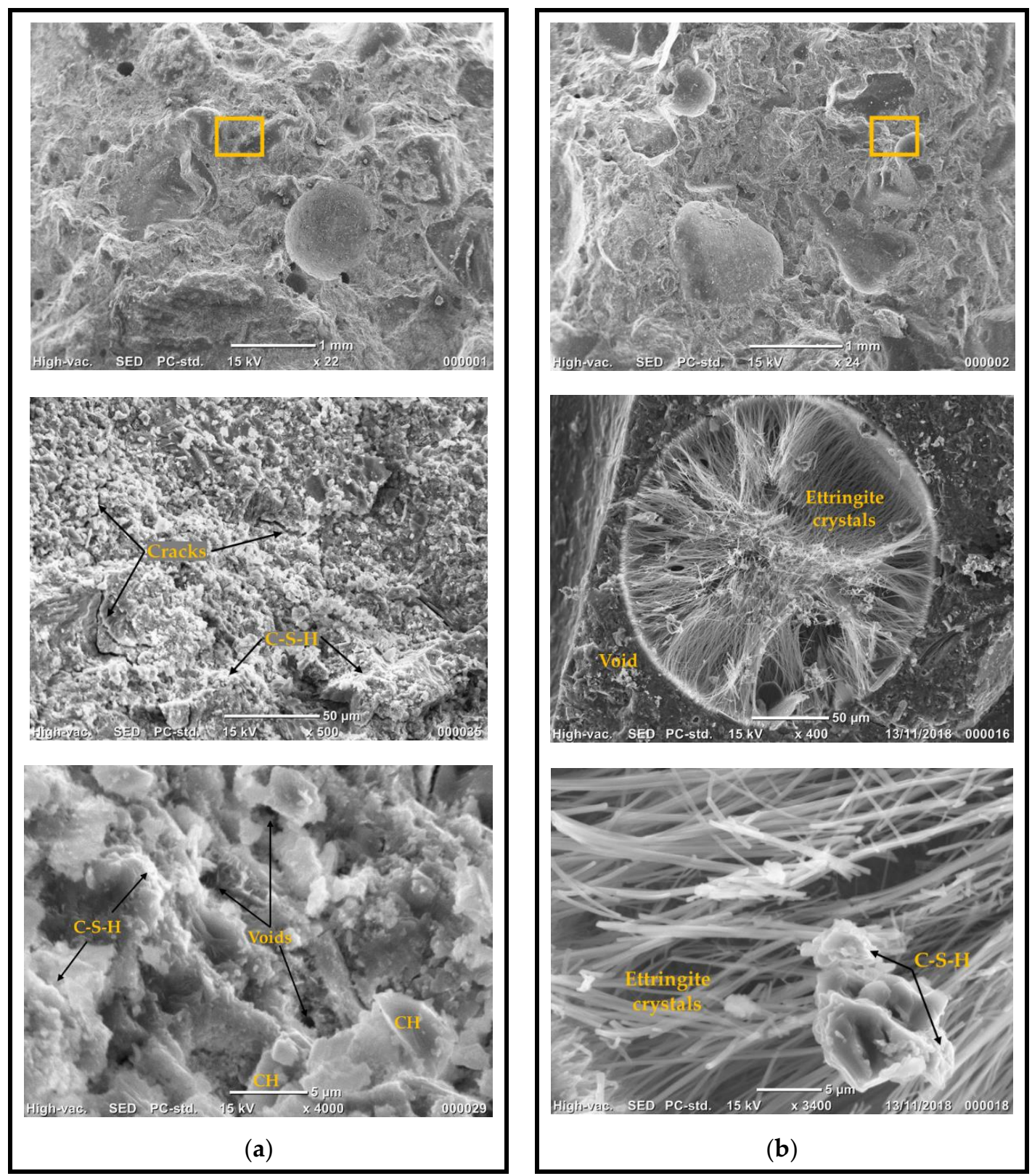

Figure 11. SEM observation at 90 days. (a) RM; (b) TSM 40-10.

\subsection{Environmental acceptability: Leaching test}

The environmental impact of the use of the sediment as an SCM with GGBS in the formulation of a ternary blended binder is evaluated by a leaching test according to the European standard EN 12457-2 [79]. The tested samples were prepared from a ground fragment taken from the investigated mortar mixtures with a liquid-to-solid ratio of 10 . 
The samples were agitated for 24 hours, then vacuum-filtered with a $0.45-\mu \mathrm{m}$-sized-pore filter before leaching. The results of the leaching test carried out on different cementitious matrices are presented in Table 9.

Table 9. Mobility of heavy metals in the studied formulations $(\mathrm{mg} / \mathrm{kg})$.

\begin{tabular}{ccccccc} 
& RM & BSM 50-0 & TSM 40-10 & TSM 35-15 & TSM 30-20 & Limit \\
\hline & $<0.11$ & $<0.11$ & $<0.11$ & $<0.11$ & $<0.11$ & 0.50 \\
$\mathrm{As}$ & 14.33 & 8.23 & 9.82 & 5.44 & 6.86 & 20.0 \\
$\mathrm{Ba}$ & $<0.009$ & $<0.009$ & $<0.009$ & $<0.009$ & $<0.009$ & 0.04 \\
$\mathrm{Cd}$ & 0.479 & 0.055 & 0.177 & 0.096 & 0.077 & 0.50 \\
$\mathrm{Cr}$ & $<0.02$ & $<0.02$ & $<0.02$ & $<0.02$ & 2.00 \\
$\mathrm{Cu}$ & $<0.02$ & $<0.09$ & 0.091 & 0.126 & 0.112 & 0.50 \\
$\mathrm{Mo}$ & $<0.09$ & $<0.05$ & $<0.05$ & $<0.05$ & $<0.05$ & 0.40 \\
$\mathrm{Ni}$ & $<0.05$ & $<0.03$ & $<0.03$ & $<0.03$ & $<0.03$ & 0.50 \\
$\mathrm{~Pb}$ & $<0.03$ & $<0.06$ & $<0.06$ & $<0.06$ & $<0.06$ & 0.06 \\
$\mathrm{Sb}$ & $<0.06$ & $<0.08$ & $<0.08$ & $<0.08$ & 0.10 \\
$\mathrm{Se}$ & $<0.08$ & $<0.08$ & $<0.08$ \\
$\mathrm{Zn}$ & $<0.01$ & $<0.01$ & $<0.01$ & $<0.01$ & $<0.01$ & 4.00 \\
Fluorides & 5.60 & 4.70 & 4.90 & 5.00 & 5.10 & 10.0 \\
Chlorides & 39.0 & 47.0 & 147 & 220 & 245 & 800 \\
Sulfates & 216 & 26.0 & 37.0 & 36.0 & 33.0 & 1000 \\
\hline
\end{tabular}

Results show that the use of ternary blended binders allows reducing the concentration of some pollutants within the cement matrix. As a matter of fact, concentrations of barium, chromium, fluorides and sulfates in sediment-based formulations are lower than those of RM formulation. In addition, molybdenum and chlorides concentrations increased. As, Cd, Cu, Ni, Pb, Sb, Se and $\mathrm{Zn}$ concentrations are under the detection thresholds for all formulations. This suggests that the use of FCS as an SCM up to $20 \%$ of substitution does not imply a chemical change in the cement matrix. Besides, concentrations of pollutants in all formulations remain below the threshold values defined in French Directive no. 0289 published on 14 December 2014 for inert waste [80].

\section{Conclusions}

Reducing the amount of $\mathrm{CO}_{2}$ associated with cement production has been a major issue in recent decades. The use of SCMs as a partial replacement of the cement contributes to the reduction of this environmental impact. This study focuses on the development of a ternary eco-binder composed of dredged sediment and slag as a partial replacement of cement (up to 50\%). A new method of sediment treatment, flash calcination, was used. The results of this study highlighted the positive impact of using ternary binders in a cement matrix on the mechanical properties of mortars. Based on these results, the following conclusions can be drawn:

- The characterization of the materials showed that sediments have a very fine granulometry $\left(\mathrm{D}_{50}=5.75 \mu \mathrm{m}\right)$ and a large specific surface area, which enhance their pozzolanic activity. In a mineralogical view, FCS contains quartz, calcite and anhydrite.

- The mixture design method was used to optimize the formulation of the ternary blended binders.

- The characterization of mortars at the fresh state showed that using FCS reduces the workability of mortars due to their important water demand and enhances the compactness. This results in an increase of density and a decrease of air content proportionally to the rate of sediment. 
- The substitution of 50\% OPC by FCS and GGBS results in a lower hydration heat peak and a delay of the initial setting time. However, the use of FCS reduces this impact thanks to its fine particles. This improvement is proportional to the quantity of FCS contained in the ternary blended binder.

- The characterization at the hardened state (compressive strength, bending strength and elastic modulus) showed that the use of 10\% FCS combined with $40 \%$ GGBS and $50 \%$ OPC (TSM 40-10) results in mechanical properties at 90 days superior to those of the control mortar RM composed of $100 \%$ OPC.

- The study of porosity showed that using FCS reduces the total porosity of mortars and the pore size, which can significantly improve their durability. SEM images highlighted the important presence of voids and portlandite in the formulation containing cement only, whereas the porosity is filled with supplementary hydration products resulting from the pozzolanic activity of FCS.

- The environmental impact of the use of ternary binders was assessed by performing leaching tests. Results showed that using FCS does not imply a chemical change in the cement matrix.

This study brought to light the beneficial effect of applying the flash calcination method on sediments for their valorization as SCMs in ternary blended binders. The durability of concretes based on ternary binders containing flash calcined sediments was investigated and will be the subject of further publications.

Author Contributions: Conceptualization, A.Z., W.M., M.B. and N.-E.A.; methodology, A.Z., W.M.; validation, A.Z., W.M.; formal analysis, A.Z.; investigation, A.Z.; data curation, A.Z.; writing-original draft preparation, A.Z.; writing - review and editing, A.Z., W.M.; visualization, A.Z.; supervision, A.Z., W.M., M.B. and N.-E.A.; project administration, M.B. and N.-E.A.; funding acquisition, M.B. and N.-E.A. All authors have read and agreed to the published version of the manuscript.

Funding: This research was funded by Chaire Ecosed.

Data Availability Statement: The data presented in this study are available on request from the corresponding author.

Acknowledgments: The authors would like to thank laboratory assistants from the laboratory of the Civil Engineering department of IMT Nord Europe, where this work was conducted, for their technical support.

Conflicts of Interest: The authors declare that they have no conflict of interest.

\section{References}

1. Benhelal, E.; Zahedi, G.; Shamsaei, E.; Bahadori, A. Global strategies and potentials to curb CO2 emissions in cement industry. J. Clean. Prod. 2013, 51, 142-161; DOI:10.1016/j.jclepro.2012.10.049.

2. Zhang, R.; Panesar, D.K. Sulfate resistance of carbonated ternary mortar blends: Portland cement, reactive MgO and supplementary cementitious materials. J. Clean. Prod. 2019, 238, 117933; DOI:10.1016/j.jclepro.2019.117933.

3. Li, R.; Lei, L.; Sui, T.; Plank, J. Effectiveness of PCE superplasticizers in calcined clay blended cements. Cem. Concr. Res. 2021, 141, 106334; DOI:10.1016/j.cemconres.2020.106334.

4. Flatt, R.J.; Roussel, N.; Cheeseman, C.R. Concrete: An eco material that needs to be improved. J. Eur. Ceram. Soc. 2012, 32, 27872798; DOI:10.1016/j.jeurceramsoc.2011.11.012.

5. Scrivener, K.L.; John, V.M.; Gartner, E.M. Eco-efficient cements: Potential economically viable solutions for a low-CO2 cementbased materials industry. Cem. Concr. Res. 2018, 114, 2-26; DOI:10.1016/j.cemconres.2018.03.015.

6. Miller, S.A.; John, V.M.; Pacca, S.A.; Horvath, A. Carbon dioxide reduction potential in the global cement industry by 2050 . Cem. Concr. Res. 2017, 114, 115-124; DOI:10.1016/j.cemconres.2017.08.026.

7. Amar, M.; Benzerzour, M.; Safhi, A.E.M.; Abriak, N.E. Durability of a cementitious matrix based on treated sediments. Case Stud. Constr. Mater. 2018, 8, 258-276; DOI:10.1016/j.cscm.2018.01.007.

8. Van Bunderen, C.; Benboudjema, F.; Snellings, R.; Vandewalle, L.; Cizer, Ö. Experimental analysis and modelling of mechanical properties and shrinkage of concrete recycling flash calcined dredging sediments. Cem. Concr. Compos. 2021, 115; DOI:10.1016/j.cemconcomp.2020.103787.

9. Benzerzour, M.; Amar, M.; Abriak, N.E. New experimental approach of the reuse of dredged sediments in a cement matrix by physical and heat treatment. Constr. Build. Mater. 2017, 140, 432-444; DOI:10.1016/j.conbuildmat.2017.02.142. 
10. Zeraoui, A.; Benzerzour, M.; Maherzi, W.; Mansi, R.; Abriak, N.E. New software for the optimization of the formulation and the treatment of dredged sediments for utilization in civil engineering. J. Soils Sediments 2020, 20, 2709-2716; DOI:10.1007/s11368-020-02605-3.

11. Siddique, R.; Khan, M.I. Supplementary Cementing Materials; Springer-Verlag: Berlin, Heidelberg, Germany, 2011.

12. Benzerzour, M.; Maherzi, W.; Amar, M.A.A.; Abriak, N.E.; Damidot, D. Formulation of mortars based on thermally treated sediments. J. Mater. Cycles Waste Manag. 2018, 20, 592-603; DOI:10.1007/s10163-017-0626-0.

13. Amar, M.; Benzerzour, M.; Abriak, N.E.; Mamindy-Pajany, Y. Study of the pozzolanic activity of a dredged sediment from Dunkirk harbour. Powder Technol. 2017, 320, 748-764; DOI:10.1016/j.powtec.2017.07.055.

14. Snellings, R.; Horckmans, L.; Van Bunderen, C.; Vandewalle, L.; Cizer, Ö. Flash-calcined dredging sediment blended cements: effect on cement hydration and properties. Mater. Struct. Constr. 2017, 50; DOI:10.1617/s11527-017-1108-5.

15. Bullerjahn, F.; Zajac, M.; Pekarkova, J.; Nied, D. Novel SCM produced by the co-calcination of aluminosilicates with dolomite. Cem. Concr. Res. 2020, 134, 106083; DOI:10.1016/j.cemconres.2020.106083.

16. Dang, T.A.; Kamali-Bernard, S.; Prince, W.A. Design of new blended cement based on marine dredged sediment. Constr. Build. Mater. 2013, 41, 602-611; DOI:10.1016/j.conbuildmat.2012.11.088.

17. Diouri, A.; Dang, T.A.; Sassi, O.; Bernard, F. Properties and hydration behavior of blended clinker and portland- sediment cement pastes. Chem. Mater. Res. 2013, 5, 27-30.

18. Faure, A.; Smith, A; Coudray, C.; Anger, B.; Colina, H.; Moulin, I.; Thery, F. Ability of Two Dam Fine-Grained Sediments to be Used in Cement Industry as Raw Material for Clinker Production and as Pozzolanic Additional Constituent of PortlandComposite Cement. Waste and Biomass Valorization 2017, 8, 2141-2163; DOI:10.1007/s12649-017-9870-8.

19. Safer, O.; Belas, N.; Belaribi, O.; Belguesmia, K.; Bouhamou, N.E.; Mebrouki, A. Valorization of Dredged Sediments as a Component of Vibrated Concrete: Durability of These Concretes Against Sulfuric Acid Attack. Int. J. Concr. Struct. Mater. 2018, 12; DOI:10.1186/s40069-018-0270-7.

20. Snellings, R.; Cizer, Ö.; Horckmans, L.; Durdziński, P.T.; Dierckx, P.; Nielsen, P.; Van Balen, K.; Vandewalle, L. Properties and pozzolanic reactivity of flash calcined dredging sediments. Appl. Clay Sci. 2016, 129, 35-39, DOI:10.1016/j.clay.2016.04.019.

21. Van Bunderen, C.; Snellings, R.; Vandewalle, L.; Cizer, Ö. Early-age hydration and autogenous deformation of cement paste containing flash calcined dredging sediments. Constr. Build. Mater. 2019, 200, 104-115; DOI:10.1016/j.conbuildmat.2018.12.090.

22. Amar, M.A.A. Traitement des sédiments de dragage pour une valorisation dans les matrices cimentaires. Ph.D. Thesis, Université Lille 1, Lille, France, 2017. (In French)

23. Amar, M.; Benzerzour, M.; Kleib, J.; Abriak, N.E. From dredged sediment to supplementary cementitious material: characterization, treatment, and reuse. Int. J. Sediment Res. 2021, 36, 92-109; DOI:10.1016/j.ijsrc.2020.06.002.

24. San Nicolas, R.; Cyr, M.; Escadeillas, G. Characteristics and applications of flash metakaolins. Appl. Clay Sci. 2013, 83-84, 253262; DOI:10.1016/j.clay.2013.08.036.

25. NF EN 197-1. Cement Part 1: Composition, specifications and conformity criteria for common cements; AFNOR - French standard institute: La Plaine Saint-Denis, France, 2012.

26. NF EN 196-1. Methods of testing cement - Part 1: Determination of strength; AFNOR - French standard institute: La Plaine SaintDenis, France, 2016.

27. NF EN 15167-1. Ground granulated blast furnace slag for use in concrete, mortar and grout - Part 1: Definitions, specifications and conformity criteria; AFNOR - French standard institute: La Plaine Saint-Denis, France, 2006.

28. LKAB Minerals. Ground Granulated Blast Furnace Slag - Ground Granulated Blast Furnace Slag (GGBS) can replace over 70\% of the Portland cement content in a concrete mix. Available online: https://www.lkabminerals.com/en/products/ggbs/ (accessed on 7 August 2021).

29. Bouhamou, N.E.; Mostefa, F.; Mebrouki, A.; Bendani, K.; Belas, N. Influence of dredged sediment on the shrinkage behavior of self-compacting concrete. Mater. Tehnol. 2016, 50, 127-135; DOI:10.17222/mit.2013.252.

30. Safhi, A.e.M.; Rivard, P.; Yahia, A.; Benzerzour, M.; Khayat, K.H. Valorization of dredged sediments in self-consolidating concrete: Fresh, hardened, and microstructural properties. J. Clean. Prod. 2020, 263, 121472; DOI:10.1016/j.jclepro.2020.121472.

31. Dixit, A.; Du, H.; Pang, S.D. Performance of mortar incorporating calcined marine clays with varying kaolinite content. J. Clean. Prod. 2021, 282, 124513; DOI:10.1016/j.jclepro.2020.124513.

32. Davies, T.W. Equipment for the study of the flash heating of particle suspensions. High Temp. Technol. 1984, 2, 141-147; DOI:10.1080/02619180.1984.11753256.

33. Inocente, J.M.; Elyseu, F.; Jaramillo Nieves, L.J.; Jiusti, J.; Cargnin, M.; Peterson, M. Production and characterization of highreactivity metakaolins calcined in flash reactor. Appl. Clay Sci.2021, 213, 106247.

34. Bucher, R.; Cyr, M.; Escadeillas, G. Performance-based evaluation of flash-metakaolin as cement replacement in marine structures - Case of chloride migration and corrosion. Constr. Build. Mater. 2021, 267; DOI:10.1016/j.conbuildmat.2020.120926.

35. NF EN 1097-7. Tests for mechanical and physical properties of aggregates - Part 7: Determination of the particle density of filler - Pycnometer method; AFNOR - French standard institute: La Plaine Saint-Denis, France, 2008.

36. NF EN ISO 18757. Determination of specific surface area of ceramic powders by gas adsorption using the BET method; AFNOR - French standard institute: La Plaine Saint-Denis, France, 2008.

37. NF EN 196-3. Methods of testing cement - Part 3 : determination of setting times and soundness; AFNOR - French standard institute: La Plaine Saint-Denis, France, 2017.

38. Claverie M.; Martin, F.; Tardy, J.P.; Cyr, M.; De Parseval, P.; Grauby, O.; Le Roux, C. Structural and chemical changes in kaolinite caused by flash calcination: Formation of spherical particles. Appl. Clay Sci. 2015, 114, 247-255; DOI:10.1016/j.clay.2015.05.031. 
39. Ilić, B.; Radonjanin, V.; Malešev, M.; Zdujić, M.; Mitrović, A. Effects of mechanical and thermal activation on pozzolanic activity of kaolin containing mica. Appl. Clay Sci. 2016, 123, 173-181; DOI:10.1016/j.clay.2016.01.029.

40. Yao, G.; Wang, Z.; Yao, J.; Cong, X.; Anning, C.; Lyu, X. Pozzolanic activity and hydration properties of feldspar after mechanical activation. Powder Technol. 2021, 383, 1-8; DOI:10.1016/j.powtec.2021.01.042.

41. Gmür, R. Influence of aging conditions upon the properties of calcined clay and its performance as supplementary cementitious material. Cem. Concr. Compos. 2016, 72, 114-124.

42. Neißer-Deiters, A.; Scherb, S.; Beuntner, N.; Thienel, K.C. Influence of the calcination temperature on the properties of a mica mineral as a suitability study for the use as SCM. Appl. Clay Sci. 2019, 179, 105168; DOI:10.1016/j.clay.2019.105168.

43. Zaitri, R.; Bederina, M.; Bouziani, T.; Makhloufi, Z.; Hadjoudja, M. Development of high performances concrete based on the addition of grinded dune sand and limestone rock using the mixture design modelling approach. Constr. Build. Mater. 2014, 60, 8-16; DOI:10.1016/j.conbuildmat.2014.02.062.

44. Akalin, O.; Akay, K.U.; Sennaroglu, B.; Tez, M. Optimization of chemical admixture for concrete on mortar performance tests using mixture experiments. Chemom. Intell. Lab. Syst. 2010, 104, 233-242; DOI:10.1016/j.chemolab.2010.08.013.

45. Bouzalakos, S.; Dudeney, A.W.L.; Chan, B.K.C. Formulating and optimising the compressive strength of controlled low-strength materials containing mine tailings by mixture design and response surface methods. Miner. Eng. 2013, 53, 48-56; DOI:10.1016/j.mineng.2013.07.007.

46. Abouhussien, A.A.; Hassan, A.A.A. Application of statistical analysis for mixture design of high-strength self-consolidating concrete containing metakaolin. J. Mater. Civ. Eng. 2014, 26, 1-9; DOI:10.1061/(ASCE)MT.1943-5533.0000944.

47. Ghafari, E.; Bandarabadi, M.; Costa, H.; Júlio, E. Prediction of fresh and hardened state properties of UHPC: Comparative study of statistical mixture design and an artificial neural network model. J. Mater. Civ. Eng. 2015, 27, 1-11; DOI:10.1061/(ASCE)MT.1943-5533.0001270.

48. Scheffé, H. The simplex-centroid design for experiments with mixtures. J. R. Stat. Soc. Ser. B Methodol. 1963, 25, $235-263$.

49. Reddy, S.V.B.; Rao, P.S. Experimental studies on compressive strength of ternary blended concretes at different levels of micro silica and ggbs. Mater. Today Proc. 2016, 3, 3752-3760; DOI:10.1016/j.matpr.2016.11.024.

50. Van Bunderen, C.; Benboudjema, F.; Snellings, R.; Vandewalle, L.; Cizer, Ö. Experimental analysis and modelling of mechanical properties and shrinkage of concrete recycling flash calcined dredging sediments. Cem. Concr. Compos. 2021, 115, 103787; DOI:10.1016/j.cemconcomp.2020.103787.

51. Cardinaud, G.; Rozière, E.; Martinage, O.; Loukili, A.; Barnes-Davin, L.; Paris, M.; Deneele, D. Calcined clay - Limestone cements: Hydration processes with high and low-grade kaolinite clays. Constr. Build. Mater. 2021, 277, 122271; DOI:10.1016/j.conbuildmat.2021.122271.

52. Gesoğlu, M.; Güneyisi, E.; Özbay, E. Properties of self-compacting concretes made with binary, ternary, and quaternary cementitious blends of fly ash, blast furnace slag, and silica fume. Constr. Build. Mater. 2009, 23, 1847-1854; DOI:10.1016/j.conbuildmat.2008.09.015.

53. Chen, J.J.; Ng, P.L.; Chu, S.H.; Guan, G.X.; Kwan, A.K.H. Ternary blending with metakaolin and silica fume to improve packing density and performance of binder paste. Constr. Build. Mater. 2020, 252, 119031; DOI:10.1016/j.conbuildmat.2020.119031.

54. Afzali-Naniz, O.; Mazloom, M. Assessment of the influence of micro- and nano-silica on the behavior of self-compacting lightweight concrete using full factorial design. Asian J. Civ. Eng. 2019, 20, 57-70; DOI:10.1007/s42107-018-0088-2.

55. De Weerdt, K.; Ben Haha, M.; Le Saout, G.; Kjellsen, K.O.; Justnes, H.; Lothenbach, B. Hydration mechanisms of ternary Portland cements containing limestone powder and fly ash. Cem. Concr. Res. 2011, 41, 279-291; DOI:10.1016/j.cemconres.2010.11.014.

56. NF EN 1015-3. Methods of test for mortar for masonry - Part 3: Determination of consistence of fresh mortar (by flow table); AFNOR French standard institute: La Plaine Saint-Denis, France, 1999.

57. NF EN 1015-6. Methods of test for mortar for masonry - Part 6 : Determination of bulk density of fresh mortar; AFNOR - French standard institute: La Plaine Saint-Denis, France, 1999.

58. NF EN 1015-7. Methods of test for mortar for masonry - Part 7: Determination of air content of fresh mortar; AFNOR - French standard institute: La Plaine Saint-Denis, France, 1999.

59. NF EN 196-3. Methods of testing cement - Part 3 : determination of setting times and soundness; AFNOR - French standard institute: La Plaine Saint-Denis, France, 2017.

60. Higl, J.; Hinder, D.; Rathgeber, C.; Ramming, B.; Lindén, M. Detailed in situ ATR-FTIR spectroscopy study of the early stages of C-S-H formation during hydration of monoclinic C3S. Cem. Concr. Res. 2021, 142, 106367; DOI:10.1016/j.cemconres.2021.106367.

61. Lu, L.; Xiang, C.; He, Y.; Wang, F.; Hu, S. Early hydration of C3S in the presence of Cd2+, Pb2+ and Cr3+ and the immobilization of heavy metals in pastes. Constr. Build. Mater. 2017, 152, 923-932; DOI:10.1016/j.conbuildmat.2017.07.026.

62. Zunino, F.; Scrivener, K. Factors influencing the sulfate balance in pure phase C3S/C3A systems. Cem. Concr. Res. 2020, 133, 106085; DOI:10.1016/j.cemconres.2020.106085.

63. Zhao, Y.; Gao, J.; Liu, C.; Chen, X.; Xu, Z. The particle-size effect of waste clay brick powder on its pozzolanic activity and properties of blended cement. J. Clean. Prod. 2020, 242, 118521; DOI:10.1016/j.jclepro.2019.118521.

64. NF EN 196-9. Methods of testing cement - Part 9: Heat of hydration - Semi-adiabatic method; AFNOR - French standard institute: La Plaine Saint-Denis, France, 2010.

65. Jacquemot, F. Accélération du durcissement des liants à base de laitier de haut fourneau pour les produits préfabriqués en béton. Ph.D. Thesis, Université Lille 1, Lille, France, 2014. (In French) 
66. Cyr, M.; Lawrence, P.; Ringot, E. Efficiency of mineral admixtures in mortars: Quantification of the physical and chemical effects of fine admixtures in relation with compressive strength. Cem. Concr. Res. 2006, 36, 264-277; DOI:10.1016/j.cemconres.2005.07.001.

67. Zairi, M.; Rouis, M.J. The influence of particle size on the pozzolanic reactivity of quartz powders. Bull. des Lab. des Ponts Chaussees 1999, $219,17$.

68. Skibsted, J.; Snellings, R. Reactivity of supplementary cementitious materials (SCMs) in cement blends. Cem. Concr. Res. 2019, 124, 105799; DOI:10.1016/j.cemconres.2019.105799

69. Nedunuri, S.S.S.A.; Sertse, S.G.; Muhammad, S. Microstructural study of Portland cement partially replaced with fly ash, ground granulated blast furnace slag and silica fume as determined by pozzolanic activity. Constr. Build. Mater. 2020, 238, 117561; DOI:10.1016/j.conbuildmat.2019.117561.

70. Li, C.; Sun, H.; Li, L. A review: The comparison between alkali-activated slag $(\mathrm{Si}+\mathrm{Ca})$ and metakaolin $(\mathrm{Si}+\mathrm{Al})$ cements. Cem . Concr. Res. 2010, 40, 1341-1349; DOI:10.1016/j.cemconres.2010.03.020.

71. Michel, M. Accélération de ciment au laitier par du ciment sulfo-alumineux. Ph.D. Thesis, INSA Lyon, Villeurbanne, France, 2009. (In French)

72. NF EN 14146. Determination of the dynamic modulus of elasticity (by measuring the fundamental resonance frequency); AFNOR - French standard institute: La Plaine Saint-Denis, France, 2004.

73. Bordy, A. Influence des conditions thermo-hydriques de conservation sur l'hydratation de matériaux cimentaires à base d'une fine recyclée. Ph.D. Thesis, Université de Cergy-Pontoise, Neuville-sur-Oise, France, 2016. (In French)

74. Zingg, L. Influence de la porosité et du degré d’humidité interne sur le comportement triaxial du béton. Ph.D. Thesis, Université de Grenoble, Saint-Martin-d'Hères, France, 2013. (In French)

75. Bajja, Z. Influence de la microstructure sur le transport diffusif des pâtes, mortiers et bétons à base de CEM I avec ajout de fumée de silice. Ph.D. Thesis, Université Paris-Saclay, Gif-sur-Yvette, 2007. (In French)

76. Bur, N. Étude des caractéristiques physico-chimiques de nouveaux bétons éco-respectueux pour leur résistance à l'environnement dans le cadre du développement durable. Ph.D. Thesis, Université de Strasbourg, Strasbourg, France, 2013. (In French)

77. Plassais, A. Nanoporosité, texture et propriétés mécaniques de pâtes de ciments. Ph.D. Thesis, Université Paris 6, Paris, France, 2003. (In French)

78. Hadj Sadok, R.; Maherzi, W.; Benzerzour, M.; Lord, R.; Torrance, K.; Zambon, A.; Abriak, N.E. Mechanical properties and microstructure of low carbon binders manufactured from calcined canal sediments and ground granulated blast furnace slag (GGBS). Sustainability 2021, 13, 9057; DOI:10.3390/su13169057.

79. NF EN 12457-2. Leaching - Compliance test for leaching of granular waste materials and sludges - Part 2: One stage batch test at a liquid to solid ratio of $10 \mathrm{l} / \mathrm{kg}$ for materials with particle size below $4 \mathrm{~mm}$; AFNOR - French standard institute: La Plaine Saint-Denis, France, 2002.

80. Ministère de l'écologie, du développement durable et de l'énergie. Arrêté du 12 décembre 2014 relatif aux conditions d'admission des déchets inertes dans les installations relevant des rubriques 2515, 2516, 2517 et dans les installations de stockage de déchets inertes de la rubrique 2760 de la nomenclature des installations classées. JORF no 0289 du 14 décembre 2014, France, 2014. (In French) 